\title{
Genetics of human iris colour and patterns
}

\author{
Richard A. Sturm ${ }^{1}$ and Mats Larsson ${ }^{2,3}$ \\ 1 Melanogenix Group, Institute for Molecular Bioscience, The University of Queensland, Brisbane, Qld, Australia \\ 2 Queensland Institute of Medical Research, Brisbane, Qld, Australia and $\mathbf{3}$ Center for Developmental Research, \\ School of Law, Psychology and Social Work, Örebro University, Örebro, Sweden \\ CORRESPONDENCE R. A. Sturm, e-mail: R.Sturm@imb.uq.edu.au
}

\author{
KEYWORDS Eye colour/melanocyte/OCA2/ \\ HERC2/quantitative trait/transcription factor/ \\ gene regulation/MITF/PAX6 \\ PUBLICATION DATA Received 27 May 2009, \\ revised and accepted for publication 6 July 2009
}

doi: $10.1111 / j .1755-148 X .2009 .00606 . x$

\section{Summary}

The presence of melanin pigment within the iris is responsible for the visual impression of human eye colouration with complex patterns also evident in this tissue, including Fuchs' crypts, nevi, Wolfflin nodules and contraction furrows. The genetic basis underlying the determination and inheritance of these traits has been the subject of debate and research from the very beginning of quantitative trait studies in humans. Although segregation of blue-brown eye colour has been described using a simple Mendelian dominant-recessive gene model this is too simplistic, and a new molecular genetic perspective is needed to fully understand the biological complexities of this process as a polygenic trait. Nevertheless, it has been estimated that $74 \%$ of the variance in human eye colour can be explained by one interval on chromosome 15 that contains the OCA2 gene. Fine mapping of this region has identified a single base change rs12913832 T/C within intron 86 of the upstream HERC2 locus that explains almost all of this association with blue-brown eye colour. A model is presented whereby this SNP, serving as a target site for the SWI/SNF family member HLTF, acts as part of a highly evolutionary conserved regulatory element required for OCA2 gene activation through chromatin remodelling. Major candidate genes possibly effecting iris patterns are also discussed, including MITF and PAX6.

\section{Introduction}

The study of human eye colour as a physical trait is based on the developmental biology, morphology, chemistry and genetic determinants of the structure known as the iris, which is part of the uveal tract of the eye (Forrester et al., 2008). The iris is a small connective tissue and muscular structure of around $12 \mathrm{~mm}$ in diameter with a central opening called the pupil (Figure 1). It controls the amount of light entering the eye which is focused by the lens onto the retina so as to provide the sense of vision. It contracts in bright light making the pupil smaller and dilates in dark conditions making the pupil larger, which together with the source of the incident light can influence the perception of an individual's eye colour and iris pattern (Figure 2). In the brown iris there is an abundance of melanocytes and melanin in the anterior border layer and stroma whereas in the blue iris these layers contain very little melanin. As light traverses these relatively melanin-free layers, collagen fibrils of the iris scatter the short blue wavelengths to the surface, thus a blue iris is a consequence of structure not of major differences in chemical composition. Different shades of blue, and in irises with a limited amount of melanin, different shades of grey, green and hazel, are determined by the thickness and density of the iris itself and the extent of accumulation of white collagen fibres, as well as patches of tissue loss in the anterior border layer and stroma.

However, a careful examination of people's irises makes it clear that there are characteristics other than eye colour that present in the human iris. The iris has been analysed to show that it can display a degree of complexity encompassing over 240 degrees of freedom (Daugman, 2003), and is probably the most complex tissue structure that is readily available on the outside of the human body. Iris tissue forms complex patterns that contain many distinct features (Figure 2B), which are currently used as biomarkers for a wide variety of 

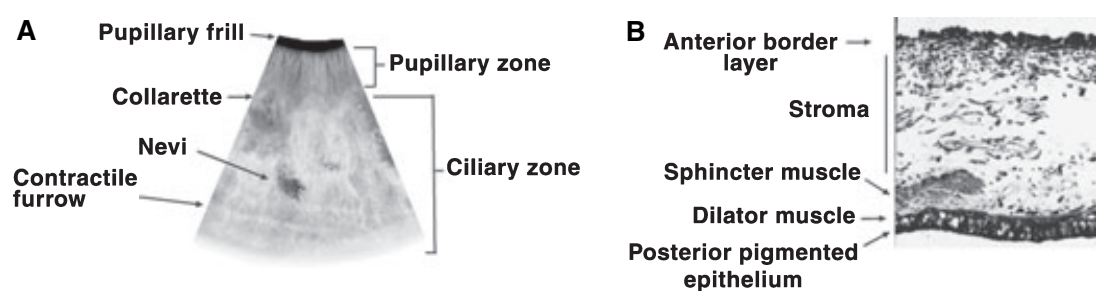

Figure 1. Human iris structure. (A) Frontal sector of the iris is shown with the collarette separating the papillary and ciliary zones. (B) A transverse view illustrating the five layers found within the iris.

different purposes. For example, the tissue patterns that are present in the human iris can serve as a reliable basis for automatic personal identification. An increasing number of banks use the iris as a mean of identification rather than pin codes. At least 1 million frequent travellers to the UK will be able to enter the country without presenting a passport or explicitly asserting their identity. Instead, their iris patterns are captured by a video camera for comparison against a database of authorized persons (Daugman, 2006). Furthermore, tissue markers in the iris are associated with eye diseases such as ocular melanoma, glaucoma (Chang et al., 1999), pigment dispersion and pseudoexfoliation syndrome (Asano et al., 1995), as well as neurological disease such as Downs Syndrome (Donaldson, 1961), Neurofibromatosis type 1 (Lee and Stephenson, 2007) and Gillespie syndrome (Marien et al., 2008; Ticho et al., 2006), which suggests that the development of the iris and brain are linked.

Moreover, genes expressed in the iris are also associated with measures of normal personality (Larsson et al., 2007), which points out that it is important to identify the genes that contribute to different iris patterns. Not only to better understand the development of different eye diseases that affect millions of people world wide every year (Friedman et al., 2004), but also to better understand how early expressing genes in the iris, are linked to brain development, and thereby potentially can contribute to identify networks of genes that influences different behavioural tendencies (Larsson et al., 2007).

\section{Morphology of the iris}

The iris consists of five cell layers, the anterior border layer, stroma, the sphincter and dilator muscles fibers, and the posterior pigment epithelium (Figure 1), of which the most important for the appearance of eye colour are the anterior layer and its underlying stroma (Eagle, 1988; Imesch et al., 1996; Wilkerson et al., 1996). Embryological studies of eye formation have established that the two pigmented layers of the iris are derived from different sources. The posterior layer is known as the iris pigment epithelium (IPE) and consists of a double layer of cuboidal pigmented cells that are tightly fused. These are of neuroectodermal origin, coming from the anterior extremity of the optic cup (Eagle, 1988). In contrast to the IPE, the stromal melanocytes are of the same embryological origin as the dermal melanocytes, in the neural crest, and migrate through the uveal tract during development. The IPE is always pigmented in the examination of the iris in all eye colours, except in individuals with albinism, and contributes little to the impression of eye colour. Where the above lying stroma is thin this layer can have some influence on patterning. For example, the dark colouration of the IPE can absorb the penetrating light in eyes with a very thin stroma, which will give the white collagen fibres in the deeper cell layers of the stroma a grey tinge (Figure 2B, panel 1). The IPE may serve a protective role for the retina by absorbing excess light that can only enter through the pupil and is not able to be reflected back out. Non-pigmented smooth muscle differentiated tissue at the stromal-IPE junction acts as the iris dilator muscle.

The two top cell layers in the iris represent the major component of the iris. The exterior anterior border layer is extremely thin, especially when it is not pigmented and consists of modified stroma cells i.e. a dense collection of fibroblasts, melanocytes and radially oriented collagen fibres. The underlying stroma consist of loose connective tissue that is made up of fibroblasts, melanocytes, collagen fibril protein (type I, III; VI and XVIII), glycosaminoglycans as well as immunological cells, such as macrophages and mast cells (Maatta et al., 2007; May, 1999; Mcmenamin, 1997; Rittig et al., 1990). The dendrites of the stromal melanocytes are generally oriented parallel to the iris surface, tend to cluster in the anterior boarder layer and in a quantitative study have been shown to represent approximately $66 \%$ of the iris stromal cells (Wilkerson et al., 1996), irrespective of eye colour.

The common occurrence of lighter iris colours is found almost exclusively in Europeans and individuals of European admixture, although it has been reported sporadically in other populations. The number of melanocytes does not appear to differ between different eye colours (Imesch et al., 1997), however it has been reported that the total number of melanocytes may be less in Asian irides compared with those of African or Europeans ancestry due to a smaller iris area or slightly lower melanocyte density (Albert et al., 2003). Ultrastructural studies of the iridial stromal melanocytes have 
A

Blue
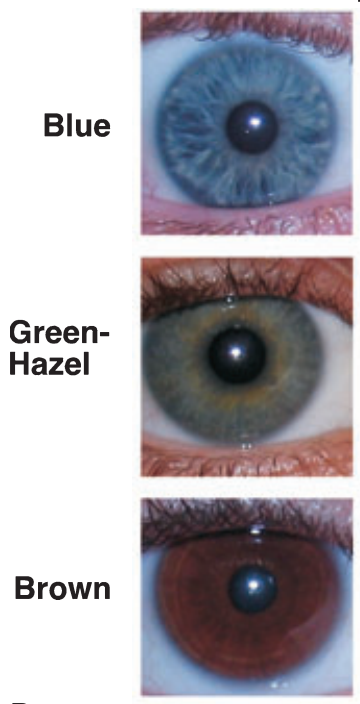

B
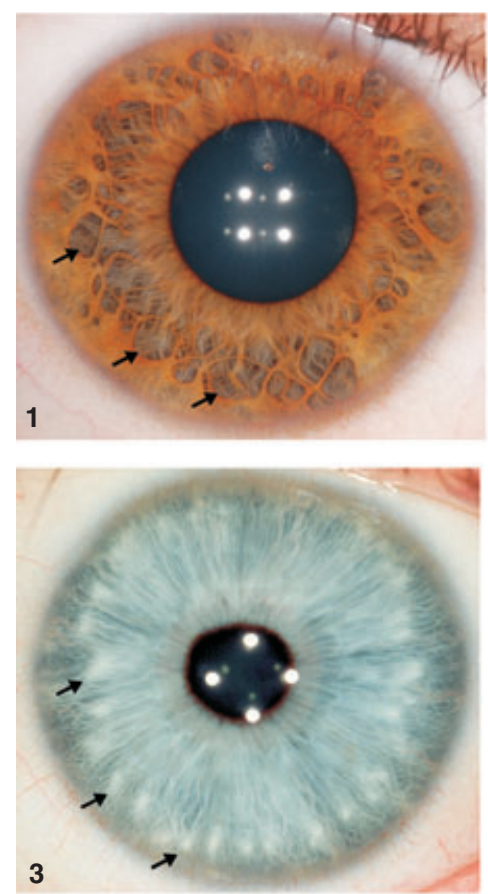

C
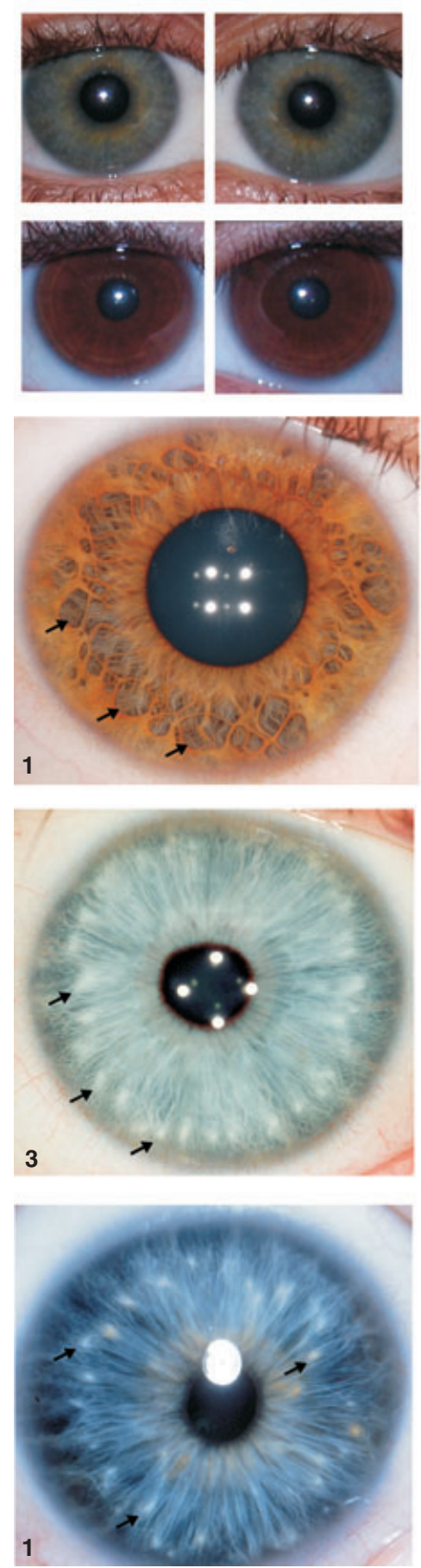
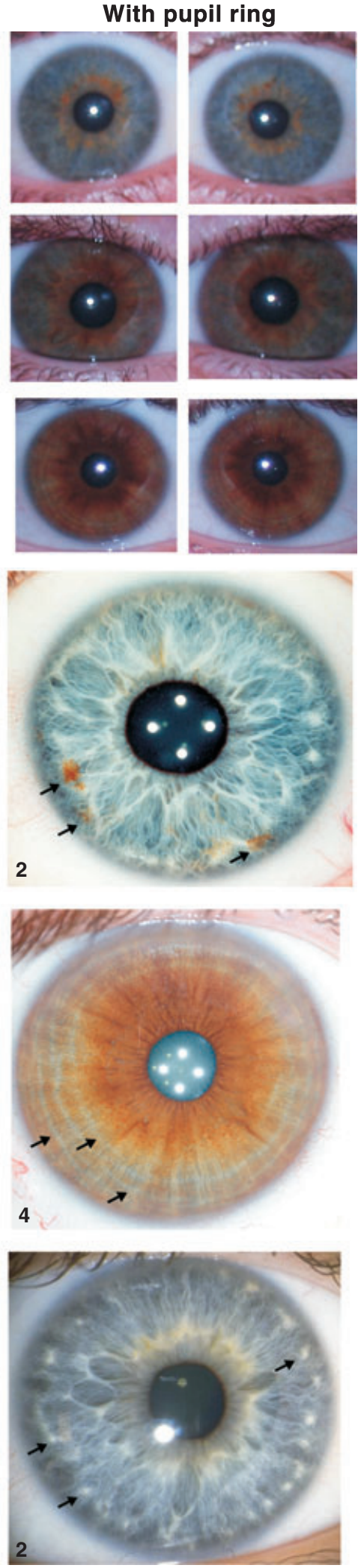

Figure 2. Human iris colour classification and patterns. (A) Three major classes of eye colour are shown as Blue, Green-Hazel, Brown with and without a brown peripupillary ring. (B) Patterns found within the iris highlighted by arrows: 1. Fuchs' Crypts, mild stroma atrophy; 2. Nevi, dots of accumulated melanin; 3. Wolfflin nodules, dots of accumulated collagen fibrils; 4. Contraction Furrows, fold marks in thicker irises due to iris contraction and dilation. (C) Patterns found within the iris highlighted by arrows: 1. Brushfield spots, observed in Downs syndrome; 2. Wolfflin nodules, observed in normal controls. 
revealed that differences in perceived eye colour are the result of variable amounts and qualities of the melanosome particles in which the melanin pigment is packaged within these cells (Eagle, 1988; Imesch et al., 1996). Unlike the skin and hair in which melanin is continuously produced and secreted, in the iris the melanosomes are retained and congest the cytoplasm of the melanocytes within the iris stroma. The quality of the melanin between eye colours has also been studied chemically, blue irides have been reported to have minimal pigment content whereas eumelanic and pheomelanic forms have been detected in other eye colours (Prota et al., 1998; Wielgus and Sarna, 2005). Notably, the quantity and type of melanin have also been correlated with iris colour, with the eumelanin:pheomelanin ratio much greater for darker eyes, whereas lighter eyes demonstrated slightly greater amounts of pheomelanin (Wakamatsu et al., 2008). Thus, the melanin pigment quantity, packaging and quality all vary, giving a spectrum of eye shades.

\section{Measures of iris colour and patterns}

Although iris colour exists in a continuum from the lightest shades of blue to the darkest of brown or black, most often only a three-point scale of blue, green-hazel and brown is used for eye colour classification (Figure 2A). It has been said that human eyes exhibit almost as much diversity as you wish to look for, and that many genetic loci must be involved (Brues, 1975). Categorization of iris colour for genetic and epidemiology studies has been performed using a variety of descriptive terms either by self-assessment with written criteria, the use of a trained observer for scoring, or grading by using defined photographic standards (Franssen et al., 2008; Seddon et al., 1990). Being somewhat subjective none of these methods are necessarily entirely reliable and as such automated photographic methods have been attempted to improve grading accuracy (Niggemann et al., 2003; Takamoto et al., 2001). One method using a digital camera and computer software to analyse light reflected from the iris has been described in detail, with the sum of a colour scale and a luminosity value used to derive a term called the Iris Melanin Index (IMI) suitable for ranking in population surveys but possibly concealing the details of iris patterns (Frudakis, 2008). Many observational studies have used the simple three-point scale and each of these eye colours can occur with or without a darker pigmented iris peripupillary ring (Figure 2A). Insufficient studies have been performed upon the nature of the peripupillary ring (Wilkerson et al., 1996), and in our own studies using digital imaging of eye colour in adolescent twins we have many grades that are harder to categorise (including partial or faint presence of the ring). Surprisingly, in this collection, $73.5 \%$ of those scored with green-hazel iris colour had the brown pupillary ring, sug- gesting what is being perceived by visual inspection without the aid of photography is actually the presence or absence of the pigmented ring on a blue background.

Observational scales for iris patterns have also been developed and in these studies (Larsson and Pedersen, 2004; Larsson et al., 2003; Lee and Stephenson, 2007), the objective has been to measure the frequency of Fuchs' crypts, nevi, Wolfflin nodules and contraction furrows (Figure $2 \mathrm{~B}$ ), which are iris characteristics that are very common in the general population and which have been studied historically by geneticists (Eskelund, 1938), anthropologists (Brues, 1946; Burkhardt, 1992) and ophthalmologists (Waardenburg, 1950). The interrater reliabilities for these scales, with five scale steps each (Larsson and Pedersen, 2004), has ranged from 0.91 to 0.97 , giving a average inter-rater reliability of about $95 \%$. That is, on average, there was only a $5 \%$ chance that the raters, when analyzing a specific tissue characteristic, would disagree in judgement on which scale step that was most appropriate. Thus, when considering the enormous diversity and complexity of the tissue structure in the human iris, the observational scales currently in use have proved to be surprisingly reliable.

\section{Eye colour: Mendelian versus quantitative trait?}

From the very beginning of quantitative studies of human genetics, eye colour has served as a paradigm for a readily observable trait that could fit, or be made to fit, the simple dominant and recessive rules of Mendelian inheritance. Galton in the UK and de Candolle in Europe in the late 19th Century both described the nonblending and alternative phenotypic nature of eye colour inheritance in families, persistence in frequencies among generations, and the important division into light and dark forms of the iris (Galton, 1886). Medium iris tints formed a minor component and intriguingly even at that time according to Galton 'It was common in them to find the outer portion of the iris to be of a dark grey colour, and the inner of hazel', consistent with the presence of the peripupillary ring in our modern studies using digital imaging. At the beginning of the 20th Century two reports appeared, one from the USA and the other from the UK, of great importance to our understanding of eye colour genetics. They studied the inheritance in families over three generations and both concluded that brown eye colour behaved as a simple dominant trait to the recessive blue; thus these constituted a pair of characters exhibiting Mendelian inheritance (Davenport and Davenport, 1907; Hurst, 1908) (Figure 3). Almost as soon as this idea was propagated, reports of eye colour inheritance inconsistent with Mendelian inheritance became apparent. Blue crossed with blue as a rule gives blue eye colour, however the rule is not without exceptions and reports of blue eyed parents 
A

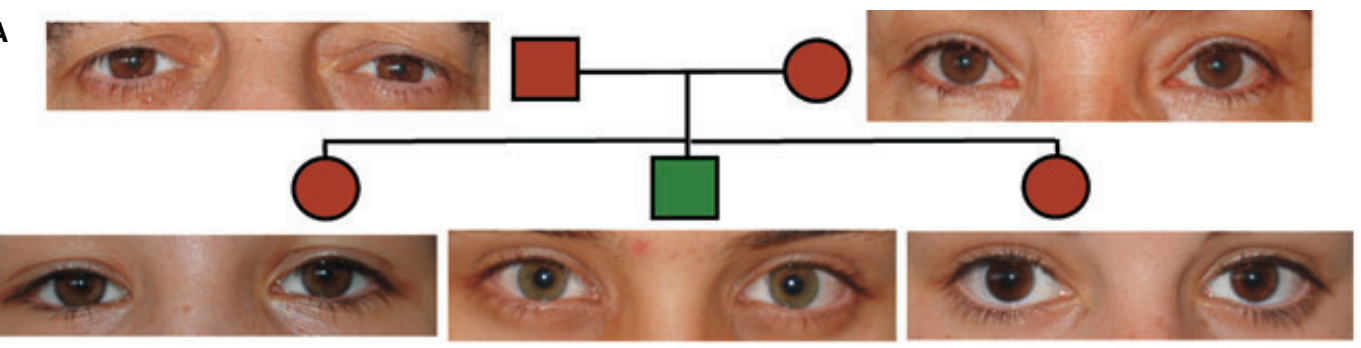

B

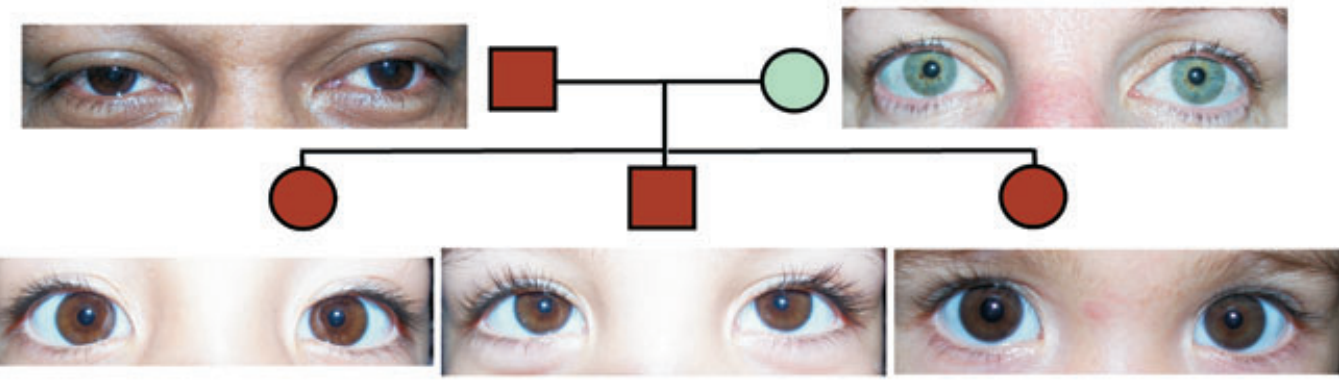

C

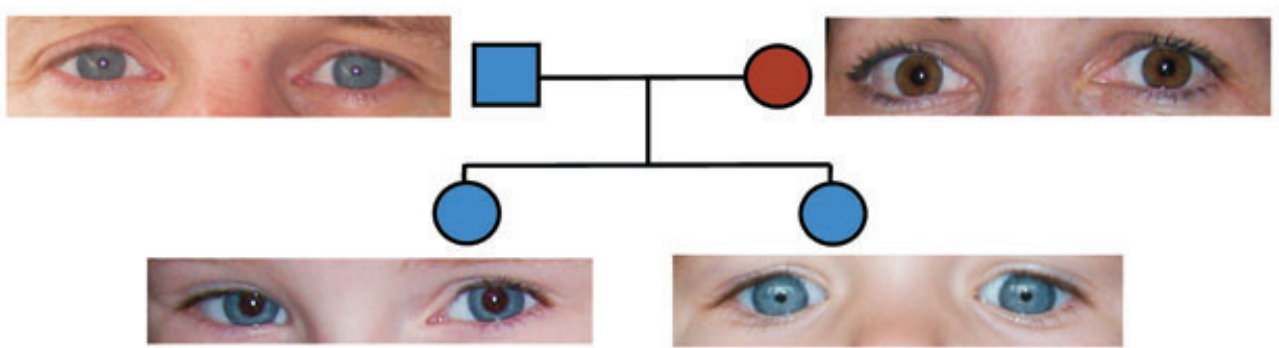

D

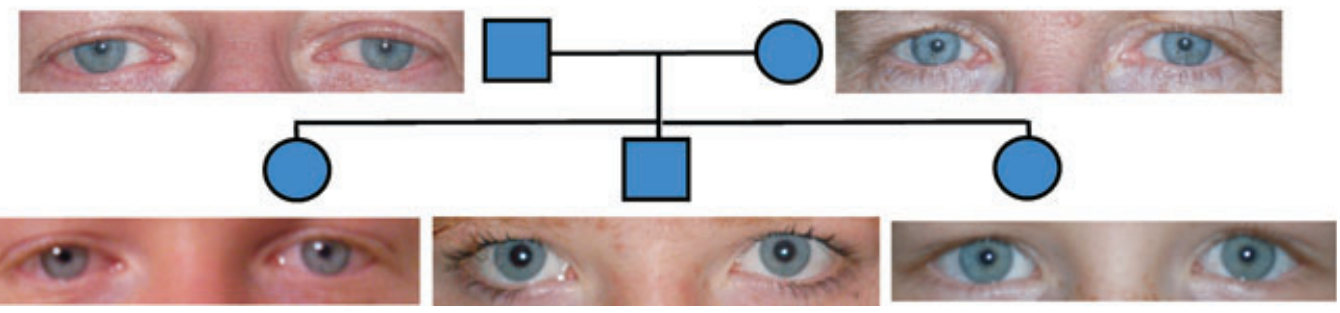

Figure 3. Inheritance of eye colour in a Mendelian fashion. The examples shown are consistent with inheritance of eye colour as a dominant Brown recessive Blue Mendelian fashion. (A) Brown $\times$ Brown giving Brown and Green. (B) Brown $\times$ Green giving Brown. (C) Blue $\times$ Brown giving Blue. (D) Blue $\times$ Blue giving Blue.

giving rise to darker or brown eye coloured offspring were reported (Holmes and Loomis, 1909; Wright, 1918), 'Much of the data obtained may be interpreted as illustrating Mendelian inheritance but it is by no means certain that it should be so interpreted' (Figure 4). Others using different techniques, such as examining just two generations but testing only in those families in which blue eyed children appeared (Boas, 1919), or comparing sibling eye colour (Brues, 1946), also found the claims unsatisfactory.

\section{Genetics of eye colour}

This has been a somewhat neglected field by both the genetics and pigmentation communities but has recently experienced a resurgence of interest. Although the use of animal models such as the mouse have been of enormous importance for gene discovery and understanding of pigmentation little comparative genetics has been used to investigate this topic. It had been noted that melanosomes from mouse pink-eyed dilution ( $p$ ) gene null mice exhibit an abnormal melanosomal ultrastructure in addition to deficient tyrosinase (TYR) activity in the choroidal melanocyte and retinal pigmented epithelial cells of the eye (Orlow and Brilliant, 1999). Moreover, a close examination of 16 mouse strains with mutations effecting melanosomes has demonstrated many of these strains do indeed provide a resource that may allow a genetic understanding of the biology of pigment formation within the iris (Anderson et al., 2008).

The first estimate of blue-brown gene allele frequencies using a dominant-recessive model for human eye 

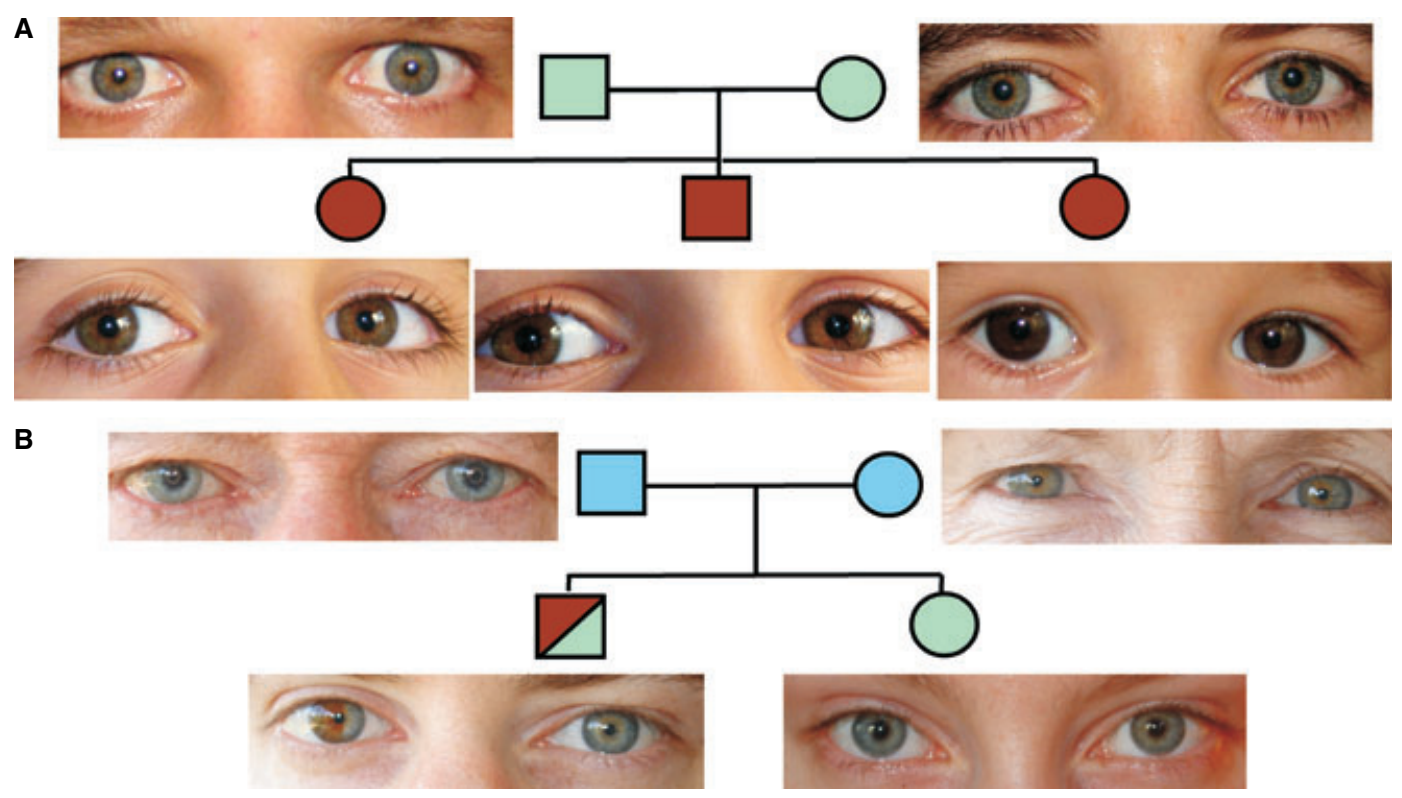

Figure 4. Inheritance of eye colour in a non-Mendelian fashion. The examples shown are inconsistent with inheritance of eye colour as a dominant Brown recessive Blue mendelian fashion. (A) Light $\times$ Light eyed parents giving Dark eyed children. (B) Blue $\times$ Blue giving a heterochromic Brown-Blue eye colour in one member of the family.

colour inheritance was performed by examining the distribution of eye colours based on a Martin-Schultz subscale classification scheme in children and parents in a large number of families from the Czechoslovak population represented by 1602 subjects (Rufer et al., 1970). The data obtained were then simply divided into light (1a-7 groupings) and dark (8-16 groupings) pigmented irises and used to impute the frequencies of a dominant gene for dark at $15.3 \%$ and a homozygous recessive gene for light at $84.7 \%$ in this collection. Later work was also performed using an essentially single gene dominant-recessive brown-blue model for eye colour inheritance on a three-point scale in a collection of 548 members of a white population from the USA comprising 53 pedigrees, estimated a frequency of $26 \%$ for the dominant brown gene (Hasstedt, 1995). However, it was conceded here in this study that other genes must contribute to expression of the green eye colour phenotype and substantial polygenic inheritance was inferred in addition to the proposed single major locus. More recently, using a similar model from data in our own collection of adolescent twins and family members within South-East Queensland, imputation of gene frequencies gave dominant-recessive allele at a single gene of $21 \%$ for brown and 79\% for blue (Duffy et al., 2007).

Attempts to link the theorized Mendelian acting genes for eye colour to human chromosomes was first performed using blood group markers. In an initial study of Danish families, positive LOD scores were reported for a diffusely brown or centrally brown eyed phenotype (symbolized as BEY1) to the Colton and Kidd blood groups found on chromosomes 7 and 18 respectively.
Another phenotype, green eye color (GEY) was mapped to chromosome 19 by linkage to Secretor and Lutheran blood groups (Eiberg and Mohr, 1987). Later work testing for segregation of DNA markers in Danish families suggested linkage of brown hair and brown eye colour (BEY2) to an interval on chromosome 15q11-15q21 containing the OCA2 and MYO5A genes (Eiberg and Mohr, 1996), with the OCA2 gene homologous to the mouse p-gene being a candidate locus responsible for the phenotype.

A complete genome microsatellite scan at the 5$10 \mathrm{cM}$ resolution level in a collection of adolescent twins in which eye colour phenotype was recorded on a three-point scale found a peak LOD score of 19.2 for blue-brown eye colour in a region that was over the OCA2 locus (Zhu et al., 2004), but with a long tail towards the telomere that may implicate other genes contributing to the phenotype. This finding was replicated in an independent set of twin pairs (Posthuma et al., 2006). Using a candidate gene approach in a sample of 629 individuals two coding region polymorphisms of OCA2 R305W and R4190 were associated with brown and green-hazel eyes respectively (Rebbeck et al., 2002), and we have also described a similar finding in the analysis of our own collection (Duffy et al., 2004), however these alleles are found at low frequency in European population so these coding region changes account for little of the variation seen in eye colour (Branicki et al., 2008; Duffy et al., 2007). Polymorphism at another locus implicated in regulation of pigmentation known as the ASIP gene has been associated with brown eye colour (Kanetsky et al., 2002). Finally, in a 
Table 1. Human pigmentation gene polymorphisms associated with eye colour

\begin{tabular}{|c|c|c|c|c|c|c|}
\hline Locus & Chromosome & Protein & $\begin{array}{l}\text { Genetic } \\
\text { disease }\end{array}$ & SNP & Amino acid & Reference \\
\hline TYR & $11 q 14.3$ & Tyrosinase & OCA1 & $\begin{array}{l}r s 1042602 C>A \\
r s 1800422 G>A \\
r s 1126809 G>A \\
r s 1393350 G>A\end{array}$ & $\begin{array}{l}\text { Ser192Tyr } \\
\text { Arg402Gln } \\
\text { Arg402Gln }\end{array}$ & $\begin{array}{l}\text { Frudakis et al. (2003); } \\
\text { Sulem et al. (2007); } \\
\text { Liu et al. (2009) }\end{array}$ \\
\hline TYRP1 & $9 p 23$ & TYRP1 & OCA3 & $\begin{array}{l}r s 1408799 C>T \\
r s 2733832 C>T \\
r s 683 C>A\end{array}$ & - & $\begin{array}{l}\text { Frudakis et al. (2003); } \\
\text { Sulem et al. (2008); } \\
\text { Liu et al. (2009) }\end{array}$ \\
\hline DCT & $13 q 32$ & DCT, TRYP2 & - & & & Frudakis et al. (2003) \\
\hline OCA2-HERC2 & $15 q 11.2-q 12$ & P-protein & OCA2 & $\begin{array}{l}r s 1800401 C>T \\
r s 1800407 G>A \\
r s 1800414 A>G \\
r s 12913832 T>C\end{array}$ & $\begin{array}{l}\text { Arg305Trp } \\
\text { Arg419GIn } \\
\text { His615Arg } \\
-\end{array}$ & $\begin{array}{l}\text { Frudakis et al. (2003); } \\
\text { Sulem et al. (2007); } \\
\text { Liu et al. (2009) See Text }\end{array}$ \\
\hline SLC45A2 & $5 p 13.3$ & MATP & OCA4 & $\begin{array}{l}r s 26722 \mathrm{G}>A \\
r s 16891982 \mathrm{G}>\mathrm{C}\end{array}$ & $\begin{array}{l}\text { Glu272Lys } \\
\text { Leu374Phe }\end{array}$ & $\begin{array}{l}\text { Frudakis et al. (2003); } \\
\text { Liu et al. (2009) }\end{array}$ \\
\hline ASIP & $20 q 11.22$ & ASIP & - & $\begin{array}{l}r s 4911442 A>G \\
r s 6058017(8818 A>G) \\
r s 1015362 A>G \\
r s 4911414 G>T\end{array}$ & & $\begin{array}{l}\text { Frudakis et al. (2003); } \\
\text { Kanetsky et al. (2002); } \\
\text { Liu et al. (2009) }\end{array}$ \\
\hline SILV & $12 q 13-q 14$ & Silver & - & & & Frudakis et al. (2003) \\
\hline MYO5A & $15 q 21$ & MyosinVa & $\begin{array}{l}\text { Griscelli } \\
\text { syndrome }\end{array}$ & & & Frudakis et al. (2003) \\
\hline IRF4 & $6 p 25.3$ & & - & $\begin{array}{l}\text { rs12203592 C > T } \\
\text { rs1540771 G > A }\end{array}$ & & Han et al. (2008); Liu et al. (2009) \\
\hline SLC24A4 & $14 q 32.12$ & SLC24A4 & - & rs12896399 G > T & & Sulem et al. (2007); Liu et al. (2009) \\
\hline
\end{tabular}

comprehensive screen using a combination of candidate genes and single nucleotide polymorphisms (SNPs) within them and others distributed throughout the genome, numerous SNPs within pigmentation related genes were identified that significantly associated with eye colour, though most of these were within the OCA2 locus (Frudakis et al., 2003).

These series of reports have previously been summarized (Sturm and Frudakis, 2004) and the genes implicated are listed in Table 1. New reports from genome-wide association studies (Gudbjartsson et al., 2008; Han et al., 2008; Kayser et al., 2008; Sulem et al., 2007, 2008) have identified a variety of pigmentation genes associated with eye colour variation, however the relative contribution of each polymorphism to this trait is yet to be fully determined and none match the major influence that the OCA2 gene plays in blue-brown eye colour variation.

\section{OCA2-HERC2 gene polymorphism}

The transcript encoded by the OCA2 locus is divided into 24 coding exons covering approximately $345 \mathrm{~kb}$ (Lee et al., 1995). The gene encodes a 838 amino acid open reading frame producing a $110 \mathrm{kD}$ protein that contains 12 transmembrane spanning regions. In the first whole genome based microsatellite screen (Zhu et al., 2004) it was estimated that one interval on chromosome 15 containing the OCA2 locus could account for $74 \%$ of variance of eye colour. Thus the major genetic determinant for blue-brown eye colour is within this region and additional studies have been directed at fine mapping of the polymorphisms that may be directly responsible for variation in iris pigmentation. A detailed population based survey of eye colour using a defined scoring system (Frudakis, 2008) tried to associate SNPs spanning the OCA2 locus with this computated numerical value. This identified 33 SNPs that could be used to define six haplotype blocks, which in turn allowed testing of those that best predicted eye colour (Frudakis et al., 2007), notably this approach confirmed the major human iris colour gene as OCA2.

We initially conducted a SNP genotyping screen covering the entire OCA2 coding region locus in an association study of eye colour (Duffy et al., 2007), and reported that a three SNP haplotype in the first intron was highly diagnostic for blue eye colour. Additional fine association mapping of eye colour SNPs in the intergenic region upstream of OCA2 and within the neighbouring HERC2 gene was then performed (Sturm et al., 2008). We screened an additional 92 SNPs in 300-3000 Caucasian individuals, and found that a single SNP in intron 86 of the adjacent HERC2 gene, rs12913832 T/C, predicted eye colour significantly better than our previous best OCA2 intron 1 three SNP haplotype. Three additional reports arising at the same time by other groups have also associated a region within the HERC2 gene 
with blue eye colour (Eiberg et al., 2008; Kayser et al., 2008; Sulem et al., 2007).

Not surprisingly this and other OCA2 polymorphisms are also significantly associated with variation in skin and hair colour (Branicki et al., 2009; Shekar et al., 2008). The proposition that eye colour can be predicted accurately from a persons genotype at the OCA2 locus (Duffy et al., 2007; Frudakis, 2008; Frudakis et al., 2007) has been extended to include other modifier loci (Table 1). A DNA-based eye colour prediction model formulated using a Dutch cohort of 6168 individuals and based on multinomial logistic regression assessed the contribution of 24 SNPs from eight genes (Liu et al., 2009). These investigators concluded that just six of these SNPS from five regions within OCA2-HERC2, SLC24A4, SLC45A2, TYR and IRF4 were the major genetic predictors of eye colour giving successful frequency predictions of 0.93 for brown, 0.91 for blue and 0.72 for intermediate coloured eyes relative to 1 for complete success. The first ranked SNP being OCA2HERC2 rs12913832 providing most of the predictive value at 0.9 brown, 0.88 blue and 0.63 intermediate. A further nine SNPs including those from the TYRP1 and ASIP loci gave minimal additive effect, with the remaining nine having no additive value, although all were significantly associated with eye colour in single SNP analysis.

\section{Model for OCA2 gene regulation as the major determinant of blue-brown eye colour}

Two reports using genetic association tests simultaneously recognized that the $\mathrm{rs} 12913832 \mathrm{~T} / \mathrm{C}$ base change within intron 86 of the HERC2 gene, $21.1 \mathrm{~kb}$ upstream of the first exon of the OCA2 gene, may account for blue-brown eye colour (Eiberg et al., 2008; Sturm et al., 2008). Apart from obvious non-synonymous coding region polymorphisms, discovery of the functional SNP variants underlying a trait is exceedingly difficult using genetic association tests alone. The additional evidence that supported rs12913832 as the key determinant of eye colour variation was its presence in the alignment of HERC2 intron 86 across many species to show a high level of evolutionary conservation. For example, there was over $77 \%$ shared sequence identity between a $406 \mathrm{bp}$ human and corresponding $420 \mathrm{bp}$ region from the mouse. Moreover, our analysis of the highly conserved 11 base sequence TGACA(T/C)TTAAT containing the centrally located rs12913832 polymorphism suggested this may represent a consensus binding site for the helicase-like transcription factor (HLTF) (Sturm et al., 2008).

Critically, this consensus sequence is abolished in the rs $12913832{ }^{*} \mathrm{C}$ blue-eyed allele. Other potential transcription factor binding sites relevant to melanocytic cell gene expression identified in this search were two strong MITF sites and three LEF1 sites (Sturm et al., 2008). Both LEF1 and MITF are critically important to gene regulation in melanocyte cell development, differentiation and tissue-specific transcription. HLTF is a member of the SWI/SNF family, DNA-dependent chromatin-remodelling ATPases that have been implicated in a wide variety of processes involving the modification of chromatin configuration to allow access of the transcriptional machinery. Another SWI/SNF family member, BRG1, has recently been shown to be involved in pigmentation pathways, being recruited by MITF to melanocyte-specific promoter regions to induce changes in chromatin structure at endogenous loci, and thus initiating the process of melanocyte differentiation (De $\mathrm{La}$ Serna et al., 2006). We therefore suggest that the presence of both MITF and HLTF enhancer sequence elements in the evolutionary conserved region of HERC2 intron 86 is a further pointer that this is a regulatory region that determines the expression of the OCA2 gene product.

A model we have proposed (Sturm et al., 2008) for how this gene regulatory mechanism serves as the molecular basis for eye colour determination is presented in Figure 5. When active, the rs12913832*T allele allows HTLF recognition and chromatin unwinding thus exposing additional regulatory sequences such as MITF and LEF1 that lead to OCA2 expression. The OCA2 protein then acts in the maturation pathway of the melanosome to produce a fully pigmented brown iris (Figure 5A). The rs $12913832{ }^{*} \mathrm{C}$ allele we propose leads to abrogation of HTLF binding, thus the chromatin remains closed and unavailable for transcription of the OCA2 locus. As a consequence of the selective loss of OCA2 production in melanocytes of the iris the inability to produce mature melanosomes results in the appearance of a blue iris (Figure 5B). In this model the failure to activate OCA2 gene expression is the most parsimonious molecular explanation.

Experimental evidence in support of a regulatory role for the conserved region within intron 86 of HERC2 on OCA2 gene expression has been provided by Eiberg et al. (Eiberg et al., 2008), who tested the effects of this region using a transcriptional reporter assay by transfection of tissue culture cell lines that included the human OCA2 immediate promoter elements in the template. Reporter constructs were prepared for brown and blue associated rs12913832 SNP alleles which were both found to be active using $\mathrm{Caco} 2$ human colon carcinoma cells. However, in contrast to an activation based model, a repression of transcription was found compared with the OCA2 immediate promoter region construct alone. Thus, the repressive action seen through transfection assays for the evolutionary conserved region of HERC2 intron 86 was used to extrapolate a transcriptional silencer function for this element in melanocytes for OCA2 gene expression. As the rs $12913832{ }^{*} \mathrm{C}$ allele to some degree alleviated this 

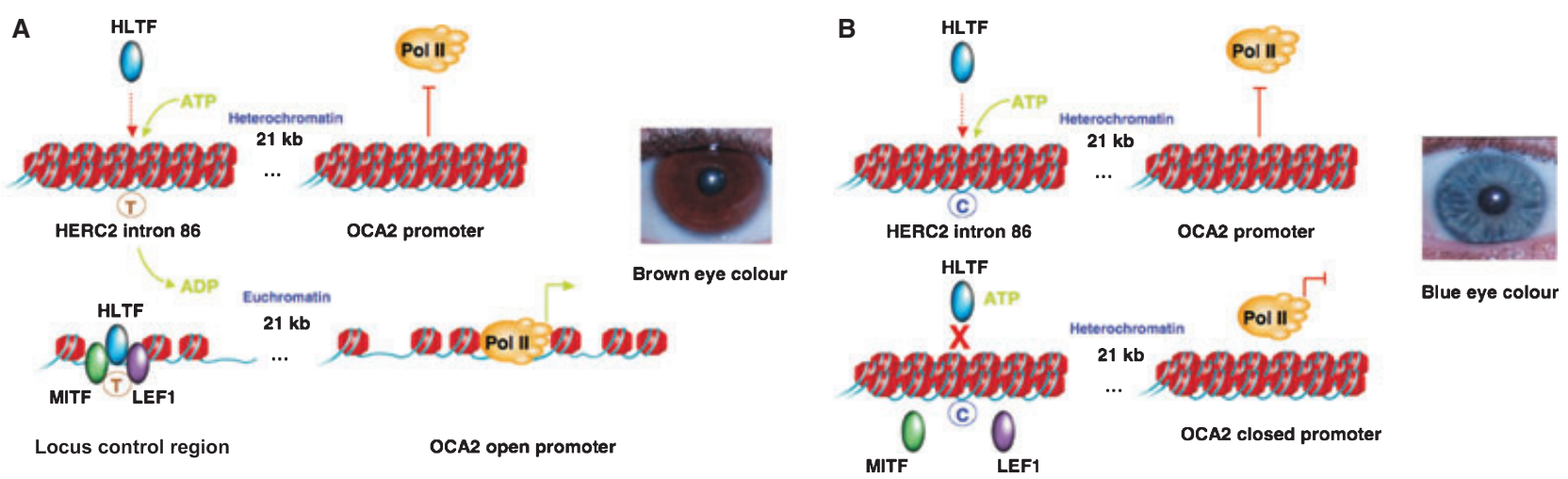

Figure 5. A model for the determination of blue-brown eye colour based upon regulation of OCA2 gene expression. (A) A cascade of molecular interactions is represented whereby the initial closed heterochromatin packaging state of the HERC2-OCA2 locus is induced to unwind into euchromatin which allows the OCA2 promoter to be open for transcription. The HLTF factor (blue) acting as sequence specific DNA recognition member of a SWI-SNF chromatin remodelling complex recognises the evolutionary conserved element containing rs12913832*T within the HERC2 intron 86 region. DNA is represented as a coil (light blue) around the nucleosome (red) which is converted from a higher order repressive state of chromatin to a more relaxed form that allows MITF (green) and LEF1 (purple) transcription factor binding to a locus control region. This nucleation acts to promulgate this change $21 \mathrm{~kb}$ downstream to the OCA2 immediate promoter region which allows RNA Polymerase II (Pol II complex in yellow) to initiate transcription (green arrow). OCA2 protein production stimulates full maturation of melanosomes and high levels of melanin in the melanocytes of the iris resulting in a brown eye colour. (B) When the rs $12913832{ }^{*} \mathrm{C}$ SNP is present within the HERC2 intron 86 region this base change prevents the interaction of HLTF with the heterochromatin (red X), the failure to bind MITF and LEF1, and as a consequence the OCA2 promoter region remains closed (red blocked arrow). The absence of OCA2 protein within the iridial melanocytes results in immature melanosomes and a loss of melanin production resulting in a blue eye colour.

repression, and differential binding of nuclear factors was seen when interactions were tested in extracts prepared from $\mathrm{Caco} 2$ cells upon probes containing the $\mathrm{T} / \mathrm{C}$ base change, their model was one of a silencer element that maybe stabilized or destabilized depending upon the presence of the rs12913832 SNP. The different mechanistic models being proposed here must be decided upon experimentally using a suitable experimental system based on the effects on gene expression in human melanocytes. Notably, a significant increase in the level of OCA2 mRNA transcript was observed in rs 12913832*T (brown) compared with rs12913832*C (blue) homozygote primary human melanocyte strains (Cook et al., 2009), consistent with this conserved element acting within a locus control region (Figure 5).

\section{Iris patterns}

\section{Heritability of iris patterns}

The extent to which genes contribute to tissue differences in the iris have only been investigated in a few studies, but in these the relative importance of genetic influences (heritability) on iris characteristics is substantial. The heritability for the frequency of Fuchs' crypts (which from now only will be called 'crypts') in the main stroma leaf, nevi, Wolfflin nodules, and the extension and distinction of contraction furrows (Figure 2B) in a German twin sample were, 66\%, 58\%, 78 and $78 \%$, respectively (Larsson et al., 2003). These findings correspond well with earlier studies in the same sample, where the intra-pair differences for 30 iris charac- teristics were such that Burkhardt (1992) concluded that nine of these were highly heritable (Burkhardt, 1992). There were no sex differences in heritability in these studies. The only iris characteristic for which heritability differs as a function of age are Wolfflin nodules, for which greater estimates were observed in the older cohorts. These findings suggest that iris characteristics in populations with normal eye development are moderately to highly heritable and generally show no sex specific genetic influences. They rule out that the variation in the overall appearance (i.e., the frequency) of these iris characteristics are due to random effects, and indicates that tissue differences in the iris can be used as a biomarker that reflect genetic differences among people.

\section{Correlation between different iris patterns and overlapping genetic effects}

One multivariate genetic analysis of the frequency of crypts, nevi, Wolfflin nodules, eye colour and the extension and distinction of contraction furrows has investigated the extent to which there is an overlap of genetic effects (i.e., a genetic correlation) among these iris characteristics (Larsson and Pedersen, 2004). The significant genetic correlations found were relatively few and low in magnitude. They fell between -0.22 and 0.44 and no evidence for significant environmental covariation was found. The structural equation models used demonstrated that the phenotypic correlation among the iris characteristics were almost entirely due to genetic covariation. 
Overall, the pattern of the genetic correlations corresponded well with what can be expected considering morphological differences during development. One such difference is the timing of formation. For instance, crypts are patch like atrophies in the two top cell layers in the iris, the anterior border layer and underlying stroma. They are formed sometime between the third and eight month of gestation and the principal distribution and depth of these atrophies are present at birth (Oyster, 1999). Pigment dots on the other hand, rarely appear on the surface of the anterior border layer before the age of six (Eagle, 1988). The genetic correlation between crypts and pigment dots is non-significant (ns) and close to zero ( $r=-0.06, n s)$, in keeping with this developmental difference. Likewise, no genetic correlation could be found between crypts and iris colour $(r=0.06, n s)$. The melanocytes, which determine iris colour (Imesch et al., 1996), normally reach their genetically determined amount of melanin in early childhood and then usually remain constant in adulthood (Bito et al., 1997). These results suggest that morphological differences during development, in this case the timing in the formation of iris characteristics, tend to preclude a potential genetic correlation.

Similarly, iris characteristics originating from the same cell layers, or cell layers that are likely to contribute to an iris characteristic's prevalence, generally do share genetic factors. For instance, contraction furrows become manifest due to a tendency of the iris to fold in the same location when the iris aperture adapts to different light conditions. The extension and distinction of contraction furrows are therefore influenced by the overall thickness and density of the iris, which implies that all five cell layers in the iris could potentially influence the extension and distinction of contraction furrows. It is therefore not surprising that all iris characteristics measured except Wolfflin nodules, i.e. the frequency of crypts, pigment dots and iris colour, shared significant genetic correlations with the extension and distinction of contraction furrows. The strongest of these was iris colour, for which the genetic influences contributing to more pigmented iris also contributed to increased extension and distinction of contraction furrows $(r=0.44$, $P<0.05)$, which indicated that the amount of melanin that is present in the iris increases to its overall density. Thus, these results suggest that the majority of the genetic effects that influence different iris characteristics are independent of each other.

\section{Genes for iris patterns}

When considering which candidate genes are most likely to influence tissue differences in the iris, the iris libraries at NEIBank (http://neibank.nei.nih.gov) are a rich source of both novel, and more well known genes. In all, the non-normalized and normalized cDNA libraries respectively, hold 1263 and 1604 clusters of expressed genes that have been identified, giving a combined total of almost 2700 potentially unique genes expressed in the human iris (Wistow et al., 2002). A quite extraordinary number, considering that most people have an iris that is only $12 \mathrm{~mm}$ wide and about $0.173-0.766 \mathrm{~mm}$ thick (Mean $=0.369 \pm 0.084 \mathrm{~mm}$ ) (Pavlin et al., 1992; Wirbelauer et al., 2005). This speaks to the rich diversity of cells that are present in the iris as well as the morphological complexity of this tissue (Forrester et al., 2008). Thus, here we will only be able to mention the candidate genes that, due to their well documented expression pattern in the iris, are most likely to contribute to frequency of crypts, nevi, Wolfflin nodules and contraction furrows, as well as give examples of how these genes can be linked to brain development, and thereby, potentially can contribute to identify networks of genes that influences different behavioural tendencies (Larsson, 2007; Larsson et al., 2007).

\section{Fuchs' crypts and contraction furrows}

Given that it potentially can be as many as 2700 genes involved in the formation of the iris, it is desirable to find the most likely candidates. Therefore, we performed an extensive literature search of the 449 genes that currently are listed by NEIBank as eye disease genes (this list can be obtained from the second author upon request). The Medline database was searched by entering the word 'iris' as well as the name of all disease genes listed. A total of 119 of the genes received at least one hit and a reading of the abstract for these studies revealed that 42 of them (Table 2) are associated with iris abnormalities (in most instances iris hypoplasia and/or a thinning of the iris) that potentially could contribute to frequency of crypts and the extension and distinction of contraction furrows (Hingorani et al., 2009). Furthermore, in an attempt to identify developmental genetic networks that contribute to the formation of specific eye structures, Thut et al. (2001) used a large scale in situ hybridization screen to survey the expression of over 1000 genes in six developmental stages in the mouse eye. This screen identified 62 genes with distinct expression patterns in various structures in the eye, adding at least eight more genes (Table 2), which due to their involvement in the embryological events that lead up to the formation of the iris, also needs to be considered as candidates for crypts and furrows. Additional developmental genes which may also influence crypt and furrow formation have recently been described (Davis-Silberman and AsheryPadan, 2008), but are not detailed here. However, as mentioned earlier, a majority of the cells in stroma, $66 \%$, are melanocytes (Wilkerson et al., 1996), and it is therefore likely that genes involved in the differentiation of melanocytes influence the frequency of crypts more than any other cell type expressed in the iris.

The MITF gene may thus be of special interest as it is required for the proper development of several cell 
Table 2. Candidate genes for Fuchs' crypt and contraction furrows

\begin{tabular}{|c|c|c|c|}
\hline No & Gene & Genome position $^{c}$ & Reference for crypt and furrow \\
\hline 1 & PAX6 & $11 \mathrm{p} 13$ & Hingorani et al. (2009); Davis-Silberman et al. (2005) \\
\hline 2 & $\mathrm{FOXC1/FOXC2}$ & $6 p 25$ & Lehmann et al. $(2003)^{a, b}$ \\
\hline 3 & PITX2 & $4 q 25-q 27$ & Kulak et al. (1998) ${ }^{a}$ \\
\hline 4. & TYR & $11 q 3$ & Morell et al. (1997) ${ }^{\text {a }}$; Gould et al. (2004) \\
\hline 5 & CYP1B1 & $2 \mathrm{p} 21$ & Vasiliou and Gonzalez (2008) $)^{\mathrm{a}, \mathrm{b}}$ \\
\hline 6 & $\mathrm{C} 3$ & $19 p 13.3-p 13.2$ & Kimura et al. $(2003)^{b}$ \\
\hline 7 & MYOC & $1 q 23-q 24$ & Swiderski et al. $(2000)^{a}$ \\
\hline 8 & OA1 & Xp22.3 & Lauronen et al. (2005) ${ }^{a}$ \\
\hline 9 & GPR143 & $\mathrm{Xp} 22.13$ & Rosenberg and Schwartz (1998) ${ }^{a}$ \\
\hline 10 & MITF & 3p14.2-p14.1 & Mochii et al. $(1998)^{b}$ \\
\hline 11 & PAX2 & $10 q 24$ & Schimmenti et al. $(2003)^{\mathrm{b}}$ \\
\hline 12 & COL18A1 & $21 q 22.3$ & Marneros and Olsen $(2003)^{b}$ \\
\hline 13 & MAF & $1 \mathrm{p} 34$ & Ahmed et al. $(2004)^{b}$; Jamieson et al. $(2003)^{a}$ \\
\hline 14 & KIT & $4 q 11-q 12$ & Kaplan and De Chaderevian (1988) ${ }^{\mathrm{a}}$, Lim et al. (2008) \\
\hline 15 & PTGS1 & $9 q 32-q 33.3$ & Wentzel et al. (2003) ${ }^{\mathrm{a}}$ \\
\hline 16 & OAT & $10 q 26$ & Vannas-Sulonen et al. $(1983)^{a} ;$ Hotta and Kato $(1989)^{b}$ \\
\hline 17 & $\mathrm{CH} \times 10$ & $14 \mathrm{q} 24.3$ & Bharti et al. $(2008)^{\mathrm{b}} ;$ Abdouh and Bernier $(2006)^{\mathrm{b}}$ \\
\hline 18 & SOX2 & $3 q 26.3-q 27$ & Wang et al. $(2008)^{\mathrm{a}}$ \\
\hline 19 & KERA & $12 q 22$ & Pressman et al. $(2000)^{a, b}$ \\
\hline 20 & LMX1B & $9 q 34$ & Pressman et al. $(2000)^{a, b}$ \\
\hline 21 & CRYAA & $21 q 22.3$ & Beby et al. $(2007)^{a}$ \\
\hline 22 & CBS & $21 q 22.3$ & Persa et al. $(2006)^{a, b}$ \\
\hline 23 & FOXE3 & $1 \mathrm{p} 32$ & Blixt et al. $(2007)^{\mathrm{b}}$ \\
\hline 24 & OPTC & $1 \mathrm{q} 32.1$ & Friedman et al. $(2002)^{a}$ \\
\hline 25 & SIX3 & $2 p 16-p 21$ & Hsieh et al. $(2002)^{\mathrm{b}}$ \\
\hline 26 & CX3CR 1 & $3 p 21.3$ & Kezic and Mcmenamin $(2008)^{\mathrm{b}}$ \\
\hline 27 & LOXL1 & $15 q 24-q 25$ & Hewitt et al. (2008) ${ }^{a}$ \\
\hline 28 & NF2 & $22 q 12.2$ & Neary et al. (1993) \\
\hline 29 & GJA1 & $6 q 21-q 23.2$ & Vasconcellos et al. $(2005)^{a}$ \\
\hline 30 & EYA1 & $8 q 13.3$ & Xu et al. $(1997)^{b}$ \\
\hline 31 & CHD7 & $8 q 12.2$ & Aramaki et al. $(2006)^{b}$ \\
\hline 32 & GLI3 & $7 p 13$ & Zaki et al. $(2006)^{\mathrm{b}}$ \\
\hline 33 & BRAF & $7 q 34$ & Henriquez et al. $(2007)^{a}$ \\
\hline 34 & COL2A1 & $12 q 13.11-q 13.2$ & Kaarniranta et al. $(2006)^{\text {b }}$ \\
\hline 35 & COL4A1 & $13 q 34$ & Van Agtmael et al. (2005) \\
\hline 36 & CTNS & $17 p 13$ & Kalatzis et al. $(2007)^{\mathrm{b}}$ \\
\hline 37 & NOTCH3 & $19 p 13.2-p 13.1$ & Roine et al. $(2006)^{a}$ \\
\hline 38 & PANK2 & $20 \mathrm{p} 13$ & Egan et al. $(2005)^{a}$ \\
\hline 39 & SALL4 & $20 q 13.13-q 13.2$ & Barry and Reddy (2008) ${ }^{a}$ \\
\hline 40 & TIMP3 & $22 q 12.1$ & Lan et al. $(2003)^{a}$ \\
\hline 41 & $\mathrm{CHM}$ & $\mathrm{Xq} 21.2$ & Funaki et al. $(2001)^{b}$ \\
\hline 42 & COL4A5 & Xq22 & Colville and Savige (1997) \\
\hline 43 & PENK & $8 q 23-q 24$ & Thut et al. $(2001)^{\mathrm{b}}$ \\
\hline 44 & CDN11 & $16 q 22.1$ & Thut et al. $(2001)^{\mathrm{b}}$ \\
\hline 45 & TGFB1 & $19 q 13.2$ & Thut et al. $(2001)^{\mathrm{b}}$ \\
\hline 46 & TMSB4X & Xq21.3-q22 & Thut et al. $(2001)^{\mathrm{b}}$ \\
\hline 47 & TGFB2 & $1 \mathrm{q} 41$ & Thut et al. $(2001)^{\mathrm{b}}$ \\
\hline 48 & COL9A1 & $6 q 12-q 14$ & Thut et al. $(2001)^{\mathrm{b}}$ \\
\hline 49 & SLC16A1 & $1 \mathrm{p} 12$ & Thut et al. $(2001)^{\mathrm{b}}$ \\
\hline 50 & TAC1 & $7 q 21-q 22$ & Thut et al. $(2001)^{b}$ \\
\hline
\end{tabular}

Number 1-42 are eye decease genes that are listed by NIEbank (in no particular order). Disease names and links to OMIM, etc are available at: http://neibank.nei.nih.gov/cgi-bin/eyeDiseaseGenes.cgi

${ }^{a}$ The empirical work is made in humans.

${ }^{\mathrm{b}}$ The empirical work is made in animals.

'The locations refers to the human genome.

lineages, including osteoclasts and natural killer cells (Hershey and Fisher, 2004). Most importantly, MITF is also required for the proper development of the melanocytes and mast cells in the stroma, as well as the pig- mented melanocytes in the IPE (Mochii et al., 1998), which gives stability to the whole iris, preventing it from touching the lens. MITF is thereby an obvious candidate gene for crypts and contraction furrows, as the overall 
thickness of the stroma and IPE contributes to the overall thickness and density of the iris (Larsson and Pedersen, 2004).

Furthermore, MITF negatively regulates the expression of PAX6 (Mochii et al., 1998; Planque et al., 2001), a highly conserved pleiotropic key regulator of a number of developmental processes (Simpson and Price, 2002). For example, the growth of the iris is causally dependent on expression of the gene PAX6 (Davis-Silberman et al., 2005). Heterozygous mutations of the PAX6 gene cause aniridia, which is characterized by a total or partial absence of the iris. Indeed, reductions in PAX6 dosage have been shown to affect the normal development of multiple organs, such as the pituitary gland (Terzic and Saraga-Babic, 1999), cerebellum, hippocampus, cerebral cortex (Hevner et al., 2006; Maekawa et al., 2005), amygdala (Kawano et al., 1999), pancreas (Sander et al., 1997), the olfactory and auditory systems (Bamiou et al., 2007; Nomura et al., 2007). PAX6 also influences the production of new neurons from stem cells in the neural crest, which is of great importance for gene networks involved brain pattering, neuronal migration, and neural circuit formation during mammalian brain development (Heins et al., 2002; Osumi et al., 2008).

In particular, it is now widely recognized that decrease or increase over the normal level of PAX6 expression leads to specific eye anterior segment defects (Sale et al., 2002; Schedl et al., 1996; Simpson and Price, 2002), and the most recent studies available suggest that PAX6 most likely influences the variability for crypt and contraction furrows (Davis-Silberman et al., 2005). Davis-Silberman et al. (2005) show that the growth of iris stroma is affected by PAX6 dosage variation in two different ways: first, it determines the size of the progenitor cells destined to an iris fate; and second, it influences the development of the iris stroma. Moreover, PAX6 is also involved in the formation of the developing sphincter and dilator muscles fibres where various feedback processes between the growing muscle fibres and stroma have been suggested to influence the embryological growth of the stroma itself (Jensen, 2005). Crypt and contraction furrows may therefore be measures that are dependent on genes that regulates PAX6, such as MITF, and downstream targets of PAX6, such as SIX3 (Hsieh et al., 2002), the OLFM3 gene (Grinchuk et al., 2005), as well as other genes, such as LMX1B (Pressman et al., 2000), HOX-7.1, HOX-8 (Monaghan et al., 1991), FOXC1, FOXC2 (Lehmann et al., 2003), PITX2 (Kulak et al., 1998) BMP7 and BMP4 (Gould et al., 2004; Jensen, 2005), which are also expressed early in the pupillary membrane, during embryological development of the iris. For example, mis-expression of PAX6, FOXC1, FOXC2 and PITX2 lead to stroma defects that are very similar to crypts, and as the expression pattern of SIX3 and OLFM3 in the iris overlaps with PAX6 expression in the iris, mutations in these genes may cause similar defects. Furthermore, all the most likely candidate genes mentioned above, without exception, are expressed both early in neural crest/neural ectoderm, as well as later in the brain and in most cases throughout the CNS, i.e. PAX6 (Heins et al., 2002; Hevner et al., 2006; Maekawa et al., 2005; Osumi et al., 2008), SIX3 (Wallis and Muenke, 2000), LMX1B (Burbach et al., 2003; Smidt et al., 2003), FOXC1, FOXC2 (Zarbalis et al., 2007), PITX2 (Bisgrove and Yost, 2001), BMP4 (Cheng et al., 2006; Sarnat and Flores-Sarnat, 2005), suggesting that these genes potentially can influence behaviour.

\section{Wolfflin nodules}

A genetic correlation between the more extended rings of Wolfflin nodules and higher frequency of crypts $(r=0.37, P<0.05)$ has been reported (Larsson and Pedersen, 2004). This suggests that Wolfflin nodules, which are dot like accumulations of mainly collagen fibres, in part, probably also contain the remaining products from the atrophy that occurs in the anterior border layer and underlying stroma. Furthermore, the histological similarity between Wolfflin nodules and Brushfield spots (Donaldson, 1961; Jaeger, 1980), and the fact that the position and appearance of Brushfield spots for patients with Down's syndrome can be quite similar to what is seen in normal controls (Figure 2C), suggests that the region on chromosome 21 that has been associated with Brushfield spots (Delabar et al., 1993), may also holds candidates genes for Wolfflin nodules. The genes ERG (Rao et al., 1987), ETS2 (Boulukos et al., 1988), HMG (Landsman et al., 1989), MX1 (Horisberger et al., 1988), WRB (Egeo et al., 1998), DSCR1 (Fuentes et al., 1995), and SH3BGR (Vidal-Taboada et al., 1997) as well as other genes which map to this region (Gosset et al., 1995), could from this perspective be potential candidate genes for Wolfflin nodules. However, normal individuals that do have mutations in some of these genes, do not always have Wolfflin nodules or Brushfield spots, indicating that the appearance of Wolfflin nodules depend on the interaction between several genes. Further research on both normal individuals with Wolfflin nodules and Down's syndrome patients with Brushfield spots needs to be performed to find out the extent to which the genetic origin of Wolfflin nodules differs from, or overlaps with, the genetic origin of Brushfield spots.

\section{Nevi}

Approximately half the adult population have iris nevi (Rees, 1976). They appear on the surface of the anterior border layer when a colony of melanocytes increases their melanin production (Eagle, 1988). Most iris melanoma behave benignly (97\%) have a finite life span (Geisse and Robertson, 1985; Jakobiec and Silbert, 1981), and generally do not carry any cytogenetic abnormalities 
(Balaban et al., 1984, 1986; Mancianti et al., 1993). The molecular changes associated with melanoma development in iris tissue are not well defined, but several authors assume that it is possible that the mechanisms controlling the progression from resting melanocytes to nevi in cutaneous melanoma, also are applicable to the melanocytes on the anterior border layer in the iris (Anastassiou et al., 2000; Hu, 2000; Kim et al., 1998; Seftor et al., 1999; Ten Berge et al., 1993). In cutaneous melanoma upregulation of the cell-cell adhesion molecules $\mathrm{N}$-cadherin, Mel-CAM/MUC18, chondroitin sulfate proteoglycan (CSPG), gangliosides $\mathrm{CD}_{3}$ and acetylated $\mathrm{GD}_{3}$, as well as downregulation of E-cadherin, P-cadherin has been identified as factors influencing the transition from normal melanocytes to nevi (Meier et al., 1998; Shih et al., 1994). To what extent these factors are relevant for the progression of iris nevi has just began to be elucidated, and there are only a few studies available that investigate the function of adhesion molecules in nevi and spindle A melanoma cells in the iris, which are known to not metastasize despite documented growth and local recurrence after excision (Geisse and Robertson, 1985). These studies show that less invasive, uveal spindle shaped cells express higher levels of $\alpha_{v} \beta_{3}$ integrin than cells of the more invasive epithelioid type, which express reduced levels of the $\alpha_{v} \beta_{3}$ integrin (Seftor et al., 1999). N-cadherin and $\beta$-catenin are also more abundant in epithelioid and invasive transitional melanoma cells than in less invasive fibroblastic or spindle melanomas cells in vitro (Kim et al., 1998). More research along these lines is needed to find out if the adhesion molecules that are associated with the progression from melanocytes to nevi in cutaneous melanoma, are also relevant for the progression of nevi in the iris. In any event, the relatively low genetic correlation between iris colour and nevi $(r=0.24, P<0.01)$, that has been reported (Larsson and Pedersen, 2004), support the idea that nevi are a further differentiated cell type which structurally resembles iris melanocytes (Dieterich, 1972; Eagle, 1988), not just hyperpigmented spots on the surface of the anterior border layer, which has been suggested by some ophthalmic textbooks (Green, 1986; Hogan et al., 1971).

Melanocytic hamartomas, the most common ocular manifestation of neurofibromatosis 1, show virtually identical ultrastructural features with typical iris nevi (Bolande, 1974; Iwamoto et al., 1972; Williamson et al., 1991) and both melanocytic hamartomas and nevi are derived from the neural crest. These findings suggests that the gene associated with neurofibromatosis 1, NF1, not only influences pigmentary lesions on the skin, such as café-au-lait spots and neurofibromas which are the most common features of neurofibromatosis 1 (Szudek et al., 2000), but also the progression of iris nevi (Charles et al., 1989; Nyormoi and Bar-Eli, 2003; Shen et al., 1996; Ticho et al., 1989). NF1 is a commonly accepted candidate gene for cutaneous and uveal mela- noma (Honavar et al., 2000; Meier et al., 1998; Nakamura, 1995). However, the prevalence rate for cutaneous and uveal melanoma of patients with neurofibromatosis is very low, only $0.1-5.4 \%$ for cutaneous melanoma and the occurrence for uveal melanoma is not more common than by chance alone (Brasfield and Das Gupta, 1972; Honavar et al., 2000). This suggests that the NF1 gene may be more closely associated with benign iris nevi than previously recognized.

Behavioural tendencies and the sensitivity of the autonomic nervous system could potentially also be associated with the prevalence of nevi in the iris, as the development of nevi in part is regulated by neurotransmitters produced by the autonomic nervous system (Hu, 2000; Mukuno and Witmer, 1977). This opens up the possibility that environmental influences also can influence frequency of nevi. For example, the extent the individual engages in withdrawal- and approach-related behaviours may produce autonomic nervous system responses producing neurotransmitters that stimulate nevi development to different degrees (Davidson and Irwin, 1999). The presence or absence of nevi may therefore be a bio-marker for how sensitive the autonomic nervous system is, and by extension, how often and persistently the individual is engaged in withdrawaland approach-related behaviours.

\section{Perspectives - what is the selection pressure on eye colour?}

Only European populations have developed a significant lightening of the pigmentation phenotypes of skin, hair and eye colour traits due to genetic selection on multiple genes (Sturm, 2009). In contrast to skin colour where the selection for lighter tones may be due to a multitude of reasons (Jablonski and Chaplin, 2000), the adaptive significance of a loss of eye colour pigmentation is less certain. The high degree of exposed white sclera eye morphology surrounding the iris apparent in humans is unique to man and has been proposed to enhance gaze signals (Kobayashi and Kohshima, 2001). Although studies on the genetics of blue eye colour have focused on OCA2-HERC2 polymorphisms in European populations, a recent study has examined SNP haplotypes in this region for an Asian group comprising 523 Japanese individuals (lida et al., 2009). Consistent with the absence of blue eye colour in this group the rs $12913832{ }^{*} \mathrm{C}$ blue-eyed allele was also absent, however the frequency of the predominant OCA2-HERC2 haplotype was found to be significantly different from that of the brown-eyed halpotype in Europeans. The reason for population specific differences in OCA2-HERC2 brown-eyed haplotype frequencies is at present unknown, but obviously not associated with eye colour.

Only two other primate species demonstrate variation in iris colour, the Macaques expressing a range from brown to blue (Zhang and Watanabe, 2007), and the Lemurs 
which are either blue or brown (Bradley et al., 2009). The genetics of these phenotypes have not be assessed in these species, but sequencing the homologous region to human HERC2 intron 86 in individual Blue and Brown-eyed Lemurs demonstrate the corresponding base change to rs12913832 does not underlie this phenotype in this species (Bradley et al., 2009). There seems to be little support to the idea that iris pigmentation might influence visual acuity in low light environments, though albinism is an exception with developmental ocular problems evident in loss of melanin synthesis capacity. However, there are reported eye colour effects on reaction time and the involvement in particular sports (Rowe and Evans, 1994), associations with shyness evident in childhood (Coplan et al., 1998), links to noise induced hearing loss (Da Costa et al., 2008), and sexual selection (Frost, 2006). There may have been coselection for lightening of pigmentary traits in humans but evidence from haplotype analysis comparing Dutch and Mediterranean population samples has been presented to suggest that blue eye colour has only arisen once during the past $10000 \mathrm{yr}$, again apart from albinism, as a founder mutation shared by diverse European populations (Eiberg et al., 2008). So if the selection for eye colour was so strong other pressures must be proposed. In this dim light it is interesting to note that reports of the ability to overcome seasonal affective disorder (SAD), a major depressive illness, is linked to lighter eye colour (Goel et al., 2002; Terman and Terman, 1999), and perhaps those with blue eyes may have been able to withstand the dark, depressing days of the Neolithic European winters better than those with brown eye colour?

\section{Acknowledgements}

We would like to thank the families that provided the eye colour photographs for Figures 3 and 4. The Melanogenix laboratory's work on human pigmentation genetics is funded in part by grants from the National Health and Medical Research Council of Australia (511191, 552485) and the Australian Research Council (DP0771169). R.A.S. is an NHMRC Senior Research Fellow. M.L. is a Postdoctoral Fellow supported by the Swedish Research Council.

\section{References}

Abdouh, M., and Bernier, G. (2006). In vivo reactivation of a quiescent cell population located in the ocular ciliary body of adult mammals. Exp. Eye Res. 83, 153-164.

Ahmed, F., Torrado, M., Zinovieva, R.D., Senatorov, V.V., Wistow, G., and Tomarev, S.I. (2004). Gene expression profile of the rat eye iridocorneal angle: NEIBank expressed sequence tag analysis. Invest. Ophthalmol. Vis. Sci. 45, 3081-3090.

Albert, D.M., Green, W.R., Zimbric, M.L., Lo, C., Gangnon, R.E., Hope, K.L., and Gleiser, J. (2003). Iris melanocyte numbers in Asian, African American, and Caucasian irides. Trans. Am. Ophthalmol. Soc. 101, 217-222.

Anastassiou, G., Schilling, H., Stang, A., Djakovic, S., Heiligenhaus, A., and Bornfeld, N. (2000). Expression of the cell adhesion mol- ecules ICAM-1, VCAM-1 and NCAM in uveal melanoma: a clinicopathological study. Oncology 58, 83-88.

Anderson, M.G., Hawes, N.L., Trantow, C.M., Chang, B., and John, S.W. (2008). Iris phenotypes and pigment dispersion caused by genes influencing pigmentation. Pigment Cell Melanoma Res. 21, 565-578.

Aramaki, M., Udaka, T., Kosaki, R. et al. (2006). Phenotypic spectrum of CHARGE syndrome with $\mathrm{CHD7}$ mutations. J. Pediatr. $148,410-414$.

Asano, N., Schlotzer-Schrehardt, U., and Naumann, G.O. (1995). A histopathologic study of iris changes in pseudoexfoliation syndrome. Ophthalmology 102, 1279-1290.

Balaban, G., Herlyn, M., Guerry, D.T., Bartolo, R., Koprowski, H., Clark, W.H., and Nowell, P.C. (1984). Cytogenetics of human malignant melanoma and premalignant lesions. Cancer Genet. Cytogenet. 11, 429-439.

Balaban, G.B., Herlyn, M., Clark Jr, W.H., and Nowell, P.C. (1986). Karyotypic evolution in human malignant melanoma. Cancer Genet. Cytogenet. 19, 113-122.

Bamiou, D.E., Free, S.L., Sisodiya, S.M., Chong, W.K., Musiek, F., Williamson, K.A., Van Heyningen, V., Moore, A.T., Gadian, D., and Luxon, L.M. (2007). Auditory interhemispheric transfer deficits, hearing difficulties, and brain magnetic resonance imaging abnormalities in children with congenital aniridia due to PAX6 mutations. Arch. Pediatr. Adolesc. Med. 161, 463469.

Barry, J.S., and Reddy, M.A. (2008). The association of an epibulbar dermoid and Duane syndrome in a patient with a SALL1 mutation (Townes-Brocks Syndrome). Ophthalmic Genet. 29, 177180.

Beby, F., Commeaux, C., Bozon, M., Denis, P., Edery, P., and Morle, L. (2007). New phenotype associated with an Arg116Cys mutation in the CRYAA gene: nuclear cataract, iris coloboma, and microphthalmia. Arch. Ophthalmol. 125, 213-216.

Bharti, K., Liu, W., Csermely, T., Bertuzzi, S., and Arnheiter, H. (2008). Alternative promoter use in eye development: the complex role and regulation of the transcription factor MITF. Development 135, 1169-1178.

Bisgrove, B.W., and Yost, H.J. (2001). Classification of left-right patterning defects in zebrafish, mice, and humans. Am. J. Med. Genet. 101, 315-323.

Bito, L.Z., Matheny, A., Cruickshanks, K.J., Nondahl, D.M., and Carino, O.B. (1997). Eye color changes past early childhood. The Louisville Twin Study. Arch. Ophthalmol. 115, 659-663.

Blixt, A., Landgren, H., Johansson, B.R., and Carlsson, P. (2007). Foxe3 is required for morphogenesis and differentiation of the anterior segment of the eye and is sensitive to Pax6 gene dosage. Dev. Biol. 302, 218-229.

Boas, H.M. (1919). Inheritance of eye-color in man. Am. J. Phys. Anthropol. 2, 15-20.

Bolande, R.P. (1974). The neurocritopathies: a unifying concept of disease arising in neural crest development. Pathology 5, 409429.

Boulukos, K.E., Pognonec, P., Begue, A., Galibert, F., Gesquiere, J.C., Stehelin, D., and Ghysdael, J. (1988). Identification in chickens of an evolutionarily conserved cellular ets-2 gene (c-ets-2) encoding nuclear proteins related to the products of the c-ets proto-oncogene. EMBO J. 7, 697-705.

Bradley, B.J., Pedersen, A., and Mundy, N.I. (2009). Brief communication: blue eyes in lemurs and humans: same phenotype, different genetic mechanism. Am. J. Phys. Anthropol. 139, 269273.

Branicki, W., Brudnik, U., Kupiec, T., Wolanska-Nowak, P., Szczerbinska, A., and Wojas-Pelc, A. (2008). Association of polymorphic 
sites in the OCA2 gene with eye colour using the tree scanning method. Ann. Hum. Genet. 72, 184-192.

Branicki, W., Brudnik, U., and Wojas-Pelc, A. (2009). Interactions between HERC2, OCA2 and MC1R may influence human pigmentation phenotype. Ann. Hum. Genet. 73, 160-170.

Brasfield, R.D., and Das Gupta, T.K. (1972). Von Recklinghausen's disease: a clinicopathological study. Ann. Surg. 175, 86-104.

Brues, A.M. (1946). A genetic analysis of human eye color. Am. J. Phys. Anthropol. 4, 1-36.

Brues, A.M. (1975). Rethingking human pigmentation. Am. J. Phys. Anthropol. 43, 387-391.

Burbach, J.P., Smits, S., and Smidt, M.P. (2003). Transcription factors in the development of midbrain dopamine neurons. Ann. N Y Acad. Sci. 991, 61-68.

Burkhardt, A. (1992). The color and structure of the human iris. 2. Studies of 200 twins. Anthropol. Anz. 50, 235-270.

Chang, B., Smith, R.S., Hawes, N.L., Anderson, M.G., Zabaleta, A., Savinova, O., Roderick, T.H., Heckenlively, J.R., Davisson, M.T., and John, S.W. (1999). Interacting loci cause severe iris atrophy and glaucoma in DBA/2J mice. Nat. Genet. 21, 405409.

Charles, S.J., Moore, A.T., Yates, J.R., and Ferguson-Smith, M.A. (1989). Lisch nodules in neurofibromatosis type 2. Case report. Arch. Ophthalmol. 107, 1571-1572.

Cheng, X., Hsu, C.M., Currle, D.S., Hu, J.S., Barkovich, A.J., and Monuki, E.S. (2006). Central roles of the roof plate in telencephalic development and holoprosencephaly. J. Neurosci. 26, 7640-7649.

Colville, D.J., and Savige, J. (1997). Alport syndrome. A review of the ocular manifestations. Ophthalmic Genet. 18, 161-173.

Cook, A.L., Chen, W., Thurber, A.E. et al. (2009). Analysis of cultured human melanocytes based on polymorphisms within the SLC45A2/MATP, SLC24A5/NCKX5, and OCA2/P loci. J. Invest. Dermatol. 129, 392-405.

Coplan, R.J., Coleman, B., and Rubin, K.H. (1998). Shyness and little boy blue: iris pigmentation, gender, and social wariness in preschoolers. Dev. Psychobiol. 32, 37-44.

Da Costa, E.A., Castro, J.C., and Macedo, M.E. (2008). Iris pigmentation and susceptibility to noise-induced hearing loss. Int. J. Audiol. 47, 115-118.

Daugman, J. (2003). The importance of being random: statistical principles of iris recognition. Pattern Recogn. 36, 279-291.

Daugman, J. (2006). Probing the uniqueness and randomness of IrisCodes: results from 200 billion iris pari comparisons. Proc. IEEE 94, 1927-1935.

Davenport, G.C., and Davenport, C.B. (1907). Heredity of eye-color in man. Science 26, 590-592.

Davidson, R.J., and Irwin, W. (1999). The functional neuroanatomy of emotion and affective style. Trends Cogn. Sci. 3, 11-21.

Davis-Silberman, N., and Ashery-Padan, R. (2008). Iris development in vertebrates; genetic and molecular considerations. Brain Res. 1192, 17-28.

Davis-Silberman, N., Kalich, T., Oron-Karni, V., Marquardt, T., Kroeber, M., Tamm, E.R., and Ashery-Padan, R. (2005). Genetic dissection of Pax6 dosage requirements in the developing mouse eye. Hum. Mol. Genet. 14, 2265-2276.

De La Serna, I.L., Ohkawa, Y., Higashi, C., Dutta, C., Osias, J., Kommajosyula, N., Tachibana, T., and Imbalzano, A.N. (2006). The microphthalmia-associated transcription factor requires SWI/SNF enzymes to activate melanocyte-specific genes. J. Biol. Chem. 281, 20233-20241.

Delabar, J.M., Theophile, D., Rahmani, Z., Chettouh, Z., Blouin, J.L., Prieur, M., Noel, B., and Sinet, P.M. (1993). Molecular mapping of twenty-four features of Down syndrome on chromosome 21. Eur. J. Hum. Genet. 1, 114-124.
Dieterich, C.E. (1972). The fine structure of melanocytes in the human iris. Albrecht Von Graefes Arch Klin. Exp. Ophthalmol. 183, 317-333.

Donaldson, D.D. (1961). The significance of the iris in mongolids: Brushfield spots. Arch. Ophthalmol. 65, 26-31.

Duffy, D.L., Box, N.F., Chen, W., Palmer, J.S., Montgomery, G.W., James, M.R., Hayward, N.K., Martin, N.G., and Sturm, R.A. (2004). Interactive effects of MC1R and OCA2 on melanoma risk phenotypes. Hum. Mol. Genet. 13, 447-461.

Duffy, D.L., Montgomery, G.W., Chen, W., Zhao, Z.Z., Le, L., James, M.R., Hayward, N.K., Martin, N.G., and Sturm, R.A. (2007). A three-single-nucleotide polymorphism haplotype in intron 1 of OCA2 explains most human eye-color variation. Am. J. Hum. Genet. 80, 241-252.

Eagle Jr, R.C. (1988). Iris pigmentation and pigmented lesions: an ultrastructural study. Trans. Am. Ophthalmol. Soc. 86, 581-687.

Egan, R.A., Weleber, R.G., Hogarth, P., Gregory, A., Coryell, J., Westaway, S.K., Gitschier, J., Das, S., and Hayflick, S.J. (2005). Neuro-ophthalmologic and electroretinographic findings in pantothenate kinase-associated neurodegeneration (formerly Hallervorden-Spatz syndrome). Am. J. Ophthalmol. 140, 267-274.

Egeo, A., Mazzocco, M., Sotgia, F., Arrigo, P., Oliva, R., Bergonon, S., Nizetic, D., Rasore-Quartino, A., and Scartezzini, P. (1998). Identification and characterization of a new human CDNA from chromosome $21 \mathrm{q} 22.3$ encoding a basic nuclear protein. Hum. Genet. 102, 289-293.

Eiberg, H., and Mohr, J. (1987). Major genes of eye color and hair color linked to LU and SE. Clin. Genet. 31, 186-191.

Eiberg, H., and Mohr, J. (1996). Assignment of genes coding for brown eye colour (BEY2) and brown hair colour (HCL3) on chromosome 15q. Eur. J. Hum. Genet. 4, 237-241.

Eiberg, H., Troelsen, J., Nielsen, M., Mikkelsen, A., Mengel-from, J., Kjaer, K.W., and Hansen, L. (2008). Blue eye color in humans may be caused by a perfectly associated founder mutation in a regulatory element located within the HERC2 gene inhibiting OCA2 expression. Hum. Genet. 123, 177-187.

Eskelund, V. (1938). Structural Variation of the Human Iris and their Heredity: with Special Reference to the Frontal Boundary Layer (Copenhagen: Busck).

Forrester, J.V., Dick, A.D., Mcmenamin, P.G., and Roberts, F. (2008). The Eye: Basic Sciences In Practice (Edinburgh, New York: Saunders Ltd).

Franssen, J., Coppens, J.E., and Van Den Berg, T.J.T.P. (2008). Grading of iris color with an extended photographic reference set. J. Optom 1, 36-40.

Friedman, J.S., Faucher, M., Hiscott, P., Biron, V.L., Malenfant, M., Turcotte, P., Raymond, V., and Walter, M.A. (2002). Protein localization in the human eye and genetic screen of opticin. Hum. Mol. Genet. 11, 1333-1342.

Friedman, D.S., Wolfs, R.C., O'colmain, B.J., Klein, B.E., Taylor, H.R., West, S., Leske, M.C., Mitchell, P., Congdon, N., and Kempen, J. (2004). Prevalence of open-angle glaucoma among adults in the United States. Arch. Ophthalmol. 122, 532-538.

Frost, P. (2006). European hair and eye color: a case of frequencydependent sexual selection? Evol. Hum. Behav. 27, 85-103.

Frudakis, T.N. (2008). Molecular Photofitting - Predicting Ancestry and Phenotype Using DNA (Burlington, MA, USA: Academic Press).

Frudakis, T., Thomas, M., Gaskin, Z., Venkateswarlu, K., Chandra, K.S., Ginjupalli, S., Gunturi, S., Natrajan, S., Ponnuswamy, V.K., and Ponnuswamy, K.N. (2003). Sequences associated with human iris pigmentation. Genetics 165, 2071-2083.

Frudakis, T., Terravainen, T., and Thomas, M. (2007). Multilocus OCA2 genotypes specify human iris colors. Hum. Genet. 122, 311-326. 
Fuentes, J.J., Pritchard, M.A., Planas, A.M., Bosch, A., Ferrer, I., and Estivill, X. (1995). A new human gene from the Down syndrome critical region encodes a proline-rich protein highly expressed in fetal brain and heart. Hum. Mol. Genet. 4, 19351944.

Funaki, H., Sawaguchi, S., Yaoeda, K. et al. (2001). Expression and localization of angiogenic inhibitory factor, chondromodulin-I, in adult rat eye. Invest. Ophthalmol. Vis. Sci. 42, 1193-1200.

Galton, F. (1886). Family likeness in eye-colour. Proc. R. Soc. Med. Lond. 40, 402-416.

Geisse, L.J., and Robertson, D.M. (1985). Iris melanomas. Am. J. Ophthalmol. 99, 638-648.

Goel, N., Terman, M., and Terman, J.S. (2002). Depressive symptomatology differentiates subgroups of patients with seasonal affective disorder. Depress Anxiety 15, 34-41.

Gosset, P., Crete, N., Ait Ghezala, G., Theophile, D., Van Broeckhoven, C., Vayssettes, C., Sinet, P.M., and Creau, N. (1995). A high-resolution map of $1.6 \mathrm{Mb}$ in the Down syndrome region: a new map between D21S55 and ETS2. Mamm. Genome 6, 127130

Gould, D.B., Smith, R.S., and John, S.W. (2004). Anterior segment development relevant to glaucoma. Int. J. Dev. Biol. 48, 10151029.

Green, W.R. (1986). The uveal tract. In Ophthalmic Pathology: an Atlas and Textbook, W.H. Spencer, ed. (Philadelphia: WB Saunders). pp. 1522-1542.

Grinchuk, O., Kozmik, Z., Wu, X., and Tomarev, S. (2005). The Optimedin gene is a downstream target of Pax6. J. Biol. Chem. 280, 35228-35237.

Gudbjartsson, D.F., Sulem, P., Stacey, S.N. et al. (2008). ASIP and TYR pigmentation variants associate with cutaneous melanoma and basal cell carcinoma. Nat. Genet. 40, 886-891.

Han, J., Kraft, P., Nan, H. et al. (2008). genome-wide association study identifies novel alleles associated with hair color and skin pigmentation. PLoS Genet. 4, e1000074.

Hasstedt, S.J. (1995). Phenotypic assortative mating in segregation analysis. Genet. Epidemiol. 12, 109-227.

Heins, N., Malatesta, P., Cecconi, F., Nakafuku, M., Tucker, K.L., Hack, M.A., Chapouton, P., Barde, Y.A., and Gotz, M. (2002). Glial cells generate neurons: the role of the transcription factor Pax6. Nat. Neurosci. 5, 308-315.

Henriquez, F., Janssen, C., Kemp, E.G., and Roberts, F. (2007). The T1799A BRAF mutation is present in iris melanoma. Invest. Ophthalmol. Vis. Sci. 48, 4897-4900.

Hershey, C.L., and Fisher, D.E. (2004). Mitf and Tfe3: members of a b-HLH-ZIP transcription factor family essential for osteoclast development and function. Bone 34, 689-696.

Hevner, R.F., Hodge, R.D., Daza, R.A., and Englund, C. (2006). Transcription factors in glutamatergic neurogenesis: conserved programs in neocortex, cerebellum, and adult hippocampus. Neurosci. Res. 55, 223-233.

Hewitt, A.W., Sharma, S., Burdon, K.P., Wang, J.J., Baird, P.N., Dimasi, D.P., Mackey, D.A., Mitchell, P., and Craig, J.E. (2008). Ancestral LOXL1 variants are associated with pseudoexfoliation in Caucasian Australians but with markedly lower penetrance than in Nordic people. Hum. Mol. Genet. 17, 710-716.

Hingorani, M., Williamson, K.A., Moore, A.T., and Van Heyningen, V. (2009). Detailed ophthalmologic evaluation of 43 individuals with PAX6 mutations. Invest. Ophthalmol. Vis. Sci. 50, 25812590.

Hogan, M.J., Alvarado, J.A., and Wedell, J.E. (1971). Histology of the Human Eye: Atlas and Textbook (Philadelphia: WB Saunders), pp. 202-255.

Holmes, S.J., and Loomis, H.M. (1909). The heredity of eye color and hair color in man. Biol. Bull. 18, 50-65.
Honavar, S.G., Singh, A.D., Shields, C.L., Shields, J.A., and Eagle Jr, R.C. (2000). Iris melanoma in a patient with neurofibromatosis. Surv. Ophthalmol. 45, 231-236.

Horisberger, M.A., Wathelet, M., Szpirer, J., Szpirer, C., Islam, Q., Levan, G., Huez, G., and Content, J. (1988). cDNA cloning and assignment to chromosome 21 of IFI-78K gene, the human equivalent of murine Mx gene. Somat. Cell Mol. Genet. 14, 123131.

Hotta, Y., and Kato, T. (1989). Ornithine aminotransferase distribution in ocular tissues and retinas of cat and mouse. Invest. Ophthalmol. Vis. Sci. 30, 1173-1177.

Hsieh, Y.W., Zhang, X.M., Lin, E., Oliver, G., and Yang, X.J. (2002). The homeobox gene Six3 is a potential regulator of anterior segment formation in the chick eye. Dev. Biol. 248, 265-280.

Hu, D.N. (2000). Regulation of growth and melanogenesis of uveal melanocytes. Pigment Cell Res. 13(Suppl 8), 81-86.

Hurst, C.C. (1908). On the inheritance of eye-colour in man. Proc. R. Soc. Med. Lond. B. Biol. Sci. 80, 85-96.

lida, R., Ueki, M., Takeshita, H., Fujihara, J., Nakajima, T., Kominato, Y., Nagao, M., and Yasuda, T. (2009). Genotyping of five single nucleotide polymorphisms in the OCA2 and HERC2 genes associated with blue-brown eye color in the Japanese population. Cell Biochem. Funct. 27, 323-327.

Imesch, P.D., Bindley, C.D., Khademian, Z., Ladd, B., Gangnon, R., Albert, D.M., and Wallow, I.H. (1996). Melanocytes and iris color. Electron microscopic findings. Arch. Ophthalmol. 114, 443-447.

Imesch, P.D., Wallow, I.H., and Albert, D.M. (1997). The color of the human eye: a review of morphologic correlates and of some conditions that affect iridial pigmentation. Surv. Ophthalmol. 41(Suppl 2), S117-S123.

Iwamoto, T., Reese, A.B., and Mund, M.L. (1972). Tapioca melanoma of the iris. 2. Electron microscopy of the melanoma cells compared with normal iris melanocytes. Am. J. Ophthalmol. 74, 851-861.

Jablonski, N.G., and Chaplin, G. (2000). The evolution of human skin coloration. J. Hum. Evol. 39, 57-106.

Jaeger, E.A. (1980). Ocular findings in Down's syndrome. Trans. Am. Ophthalmol. Soc. 78, 808-845.

Jakobiec, F.A., and Silbert, G. (1981). Are most iris "melanomas' really nevi? A clinicopathologic study of 189 lesions Arch. Ophthalmol. 99, 2117-2132.

Jamieson, R.V., Munier, F., Balmer, A., Farrar, N., Perveen, R., and Black, G.C. (2003). Pulverulent cataract with variably associated microcornea and iris coloboma in a MAF mutation family. Br. J. Ophthalmol. 87, 411-412.

Jensen, A.M. (2005). Potential roles for BMP and Pax genes in the development of iris smooth muscle. Dev. Dyn. 232, 385392.

Kaarniranta, K., Ihanamaki, T., Sahlman, J., Pulkkinen, H., Uusitalo, H., Arita, M., Tammi, R., Lammi, M.J., and Helminen, H.J. (2006). A mouse model for Stickler's syndrome: ocular phenotype of mice carrying a targeted heterozygous inactivation of type II (pro)collagen gene (Col2a1). Exp. Eye Res. 83, 297-303.

Kalatzis, V., Serratrice, N., Hippert, C. et al. (2007). The ocular anomalies in a cystinosis animal model mimic disease pathogenesis. Pediatr. Res. 62, 156-162.

Kanetsky, P.A., Swoyer, J., Panossian, S., Holmes, R., Guerry, D., and Rebbeck, T.R. (2002). A polymorphism in the agouti signaling protein gene is associated with human pigmentation. Am. J. Hum. Genet. 70, 770-775.

Kaplan, P., and De Chaderevian, J.P. (1988). Piebaldism-Waardenburg syndrome: histopathologic evidence for a neural crest syndrome. Am. J. Med. Genet. 31, 679-688.

Kawano, H., Fukuda, T., Kubo, K., Horie, M., Uyemura, K., Takeuchi, K., Osumi, N., Eto, K., and Kawamura, K. (1999). Pax-6 is 
required for thalamocortical pathway formation in fetal rats. J. Comp. Neurol. 408, 147-160.

Kayser, M., Liu, F., Janssens, A.C. et al. (2008). Three Genomewide association studies and a linkage analysis identify HERC2 as a human iris color gene. Am. J. Hum. Genet. 82, 411-423.

Kezic, J., and Mcmenamin, P.G. (2008). Differential turnover rates of monocyte-derived cells in varied ocular tissue microenvironments. J. Leukoc. Biol. 84, 721-729.

Kim, K., Daniels, K.J., and Hay, E.D. (1998). Tissue-specific expression of beta-catenin in normal mesenchyme and uveal melanomas and its effect on invasiveness. Exp. Cell Res. 245, 79-90.

Kimura, Y., Madhavan, M., Call, M.K., Santiago, W., Tsonis, P.A., Lambris, J.D., and Del Rio-Tsonis, K. (2003). Expression of complement 3 and complement 5 in newt limb and lens regeneration. J. Immunol. 170, 2331-2339.

Kobayashi, H., and Kohshima, S. (2001). Unique morphology of the human eye and its adaptive meaning: comparative studies on external morphology of the primate eye. J. Hum. Evol. 40, 419-435.

Kulak, S.C., Kozlowski, K., Semina, E.V., Pearce, W.G., and Walter, M.A. (1998). Mutation in the RIEG1 gene in patients with iridogoniodysgenesis syndrome. Hum. Mol. Genet. 7, 1113-1117.

Lan, J., Kumar, R.K., Di Girolamo, N., Mccluskey, P., and Wakefield, D. (2003). Expression and distribution of matrix metalloproteinases and their inhibitors in the human iris and ciliary body. Br. J. Ophthalmol. 87, 208-211.

Landsman, D., Mcbride, O.W., Soares, N., Crippa, M.P., Srikantha, T., and Bustin, M. (1989). Chromosomal protein HMG-14. Identification, characterization, and chromosome localization of a functional gene from the large human multigene family. J. Biol. Chem. 264 3421-3427.

Larsson, M. (2007). Human Iris Characteristics as Biomarkers for Personality. Örebro studies in psychology. 1 (Dissertational work) ed. Örebro, Sweden (Sweden: Dissertational work at Örebro University).

Larsson, M., and Pedersen, N.L. (2004). Genetic correlations among texture characteristics in the human iris. Mol. Vis. 10, 821-831.

Larsson, M., Pedersen, N.L., and Stattin, H. (2003). Importance of genetic effects for characteristics of the human iris. Twin Res. 6 , 192-200.

Larsson, M., Pedersen, N.L., and Stattin, H. (2007). Associations between iris characteristics and personality in adulthood. Biol. Psychol. 75, 165-175.

Lauronen, L., Jalkanen, R., Huttunen, J., Carlsson, E., Tuupanen, S., Lindh, S., Forsius, H., Sankila, E.M., and Alitalo, T. (2005). Abnormal crossing of the optic fibres shown by evoked magnetic fields in patients with ocular albinism with a novel mutation in the OA1 gene. Br. J. Ophthalmol. 89, 820-824.

Lee, M.J., and Stephenson, D.A. (2007). Recent developments in neurofibromatosis type 1. Curr. Opin. Neurol. 20, 135-341.

Lee, S.T., Nicholls, R.D., Jong, M.T., Fukai, K., and Spritz, R.A. (1995). Organization and sequence of the human $P$ gene and identification of a new family of transport proteins. Genomics 26, 354-363.

Lehmann, O.J., Sowden, J.C., Carlsson, P., Jordan, T., and Bhattacharya, S.S. (2003). Fox's in development and disease. Trends Genet. 19, 339-344.

Lim, K.H., Pardanani, A., and Tefferi, A. (2008). KIT and mastocytosis. Acta Haematol. 119, 194-198.

Liu, F., Van Duijn, K., Vingerling, J.R., Hofman, A., Uitterlinden, A.G., Janssens, A.C., and Kayser, M. (2009). Eye color and the prediction of complex phenotypes from genotypes. Curr. Biol. 19, R192-R193.
Maatta, M., Heljasvaara, R., Pihlajaniemi, T., and Uusitalo, M. (2007). Collagen XVIII/endostatin shows a ubiquitous distribution in human ocular tissues and endostatin-containing fragments accumulate in ocular fluid samples. Graefes Arch. Clin. Exp. Ophthalmol. 245, 74-81.

Maekawa, M., Takashima, N., Arai, Y., Nomura, T., Inokuchi, K., Yuasa, S., and Osumi, N. (2005). Pax6 is required for production and maintenance of progenitor cells in postnatal hippocampal neurogenesis. Genes Cells 10, 1001-1014.

Mancianti, M.L., Gyorfi, T., Shih, I.M., Valyi-Nagy, I., Levengood, G., Menssen, H.D., Halpern, A.C., Elder, D.E., and Herlyn, M. (1993). Growth regulation of cultured human nevus cells. J. Invest. Dermatol. 100, 281S-287S.

Marien, P., Brouns, R., Engelborghs, S., Wackenier, P., Verhoeven, J., Ceulemans, B., and De Deyn, P.P. (2008). Cerebellar cognitive affective syndrome without global mental retardation in two relatives with Gillespie syndrome. Cortex 44, 54-67.

Marneros, A.G., and Olsen, B.R. (2003). Age-dependent iris abnormalities in collagen XVIII/endostatin deficient mice with similarities to human pigment dispersion syndrome. Invest. Ophthalmol. Vis. Sci. 44, 2367-2372.

May, C.A. (1999). Mast cell heterogeneity in the human uvea. Histochem. Cell Biol. 112, 381-386.

Mcmenamin, P.G. (1997). The distribution of immune cells in the uveal tract of the normal eye. Eye 11(Pt 2), 183-193.

Meier, F., Satyamoorthy, K., Nesbit, M., Hsu, M.Y., Schittek, B., Garbe, C., and Herlyn, M. (1998). Molecular events in melanoma development and progression. Front. Biosci. 3, D1005D1010.

Mochii, M., Mazaki, Y., Mizuno, N., Hayashi, H., and Eguchi, G. (1998). Role of Mitf in differentiation and transdifferentiation of chicken pigmented epithelial cell. Dev. Biol. 193, 47-62.

Monaghan, A.P., Davidson, D.R., Sime, C., Graham, E., Baldock, R., Bhattacharya, S.S., and Hill, R.E. (1991). The Msh-like homeobox genes define domains in the developing vertebrate eye. Development 112, 1053-1061.

Morell, R., Spritz, R.A., Ho, L., Pierpont, J., Guo, W., Friedman, T.B., and Asher Jr, J.H. (1997). Apparent digenic inheritance of Waardenburg syndrome type 2 (WS2) and autosomal recessive ocular albinism (AROA). Hum. Mol. Genet. 6, 659-664.

Mukuno, K., and Witmer, R. (1977). Innervation of melanocytes in human iris. An electron microscopic study. Albrecht Von Graefes Archiv fur Klinische und Experimentelle. Ophthalmologie 203, $1-8$.

Nakamura, T. (1995). Genetic markers and animal models of neurocristopathy. Histol. Histopathol. 10, 747-759.

Neary, W.J., Newton, V.E., Vidler, M., Ramsden, R.T., Lye, R.H., Dutton, J.E., Richardson, P.L., Harris, R., Evans, D.G., and Strachan, T. (1993). A clinical, genetic and audiological study of patients and families with bilateral acoustic neurofibromatosis. J. Laryngol. Otol. 107, 6-11.

Niggemann, B., Weinbauer, G., Vogel, F., and Korte, R. (2003). A standardized approach for iris color determination. Int. J. Toxicol. 22, 49-51.

Nomura, T., Haba, H., and Osumi, N. (2007). Role of a transcription factor Pax6 in the developing vertebrate olfactory system. Dev Growth Differ. 49, 683-690.

Nyormoi, O., and Bar-Eli, M. (2003). Transcriptional regulation of metastasis-related genes in human melanoma. Clin. Exp. Metastasis 20, 251-263.

Orlow, S.J., and Brilliant, M.H. (1999). The pink-eyed dilution locus controls the biogenesis of melanosomes and levels of melanosomal proteins in the eye. Exp. Eye Res. 68, 147-154.

Osumi, N., Shinohara, H., Numayama-Tsuruta, K., and Maekawa, M. (2008). Concise review: Pax6 transcription factor contributes 
to both embryonic and adult neurogenesis as a multifunctional regulator. Stem Cells 26, 1663-1672.

Oyster, C.W. (1999). The Human Eye Structure and Function (Sunderland (MA): Sinauer Associates).

Pavlin, C.J., Harasiewicz, K., and Foster, F.S. (1992). Ultrasound biomicroscopy of anterior segment structures in normal and glaucomatous eyes. Am. J. Ophthalmol. 113, 381-389.

Persa, C., Osmotherly, K., Chao-Wei Chen, K., Moon, S., and Lou, M.F. (2006). The distribution of cystathionine beta-synthase (CBS) in the eye: implication of the presence of a trans-sulfuration pathway for oxidative stress defense. Exp. Eye Res. 83, 817-823.

Planque, N., Leconte, L., Coquelle, F.M., Martin, P., and Saule, S. (2001). Specific Pax-6/microphthalmia transcription factor interactions involve their DNA-binding domains and inhibit transcriptional properties of both proteins. J. Biol. Chem. 276, 29330-29337.

Posthuma, D., Visscher, P.M., Willemsen, G., Zhu, G., Martin, N.G., Slagboom, P.E., De Geus, E.J., and Boomsma, D.I. (2006). Replicated linkage for eye color on $15 q$ using comparative ratings of sibling pairs. Behav. Genet. 36, 12-17.

Pressman, C.L., Chen, H., and Johnson, R.L. (2000). LMX1B, a LIM homeodomain class transcription factor, is necessary for normal development of multiple tissues in the anterior segment of the murine eye. Genesis 26, 15-25.

Prota, G., Hu, D.N., Vincensi, M.R., Mccormick, S.A., and Napolitano, A. (1998). Characterization of melanins in human irides and cultured uveal melanocytes from eyes of different colors. Exp. Eye Res. 67, 293-299.

Rao, V.N., Papas, T.S., and Reddy, E.S. (1987). ERG, a human etsrelated gene on chromosome 21: alternative splicing, polyadenylation, and translation. Science 237, 635-639.

Rebbeck, T.R., Kanetsky, P.A., Walker, A.H., Holmes, R., Halpern, A.C., Schuchter, L.M., Elder, D.E., and Guerry, D. (2002). P gene as an inherited biomarker of human eye color. Cancer Epidemiol. Biomarkers Prev. 11, 782-784.

Rees, A.B. (1976). Tumors of the Eye (Hagerstown: Haper \& Row) p.229.

Rittig, M., Lutjen-Drecoll, E., Rauterberg, J., Jander, R., and Mollenhauer, J. (1990). Type-VI collagen in the human iris and ciliary body. Cell Tissue Res. 259, 305-312.

Roine, S., Harju, M., Kivela, T.T., Poyhonen, M., Nikoskelainen, E., Tuisku, S., Kalimo, H., Viitanen, M., and Summanen, P.A. (2006). Ophthalmologic findings in cerebral autosomal dominant arteriopathy with subcortical infarcts and leukoencephalopathy: a crosssectional study. Ophthalmology 113, 1411-1417.

Rosenberg, T., and Schwartz, M. (1998). X-linked ocular albinism: prevalence and mutations-a national study. Eur. J. Hum. Genet. 6, 570-577.

Rowe, P.J., and Evans, P. (1994). Ball color, eye color, and a reactive motor skill. Percept. Mot. Skills 79, 671-674.

Rufer, V., Bauer, J., and Soukup, F. (1970). On the heredity of eye colour. Acta Univ. Carol. [Med] (Praha) 16, 429-434.

Sale, M.M., Craig, J.E., Charlesworth, J.C., Fitzgerald, L.M., Hanson, I.M., Dickinson, J.L., Matthews, S.J., Heyningen, V., Fingert, J.H., and Mackey, D.A. (2002). Broad phenotypic variability in a single pedigree with a novel 1410 delC mutation in the PST domain of the PAX6 gene. Hum. Mutat. 20, 322.

Sander, M., Neubuser, A., Kalamaras, J., Ee, H.C., Martin, G.R., and German, M.S. (1997). Genetic analysis reveals that PAX6 is required for normal transcription of pancreatic hormone genes and islet development. Genes Dev. 11, 1662-1673.

Sarnat, H.B., and Flores-Sarnat, L. (2005). Embryology of the neural crest: its inductive role in the neurocutaneous syndromes. J. Child Neurol. 20,637-643.
Schedl, A., Ross, A., Lee, M., Engelkamp, D., Rashbass, P., Van Heyningen, V., and Hastie, N.D. (1996). Influence of PAX6 gene dosage on development: overexpression causes severe eye abnormalities. Cell 86, 71-82.

Schimmenti, L.A., De La Cruz, J., Lewis, R.A., Karkera, J.D., Manligas, G.S., Roessler, E., and Muenke, M. (2003). Novel mutation in sonic hedgehog in non-syndromic colobomatous microphthalmia. Am. J. Med. Genet. A. 116A, 215-221.

Seddon, J.M., Sahagian, C.R., Glynn, R.J., Sperduto, R.D., and Gragoudas, E.S. (1990). Evaluation of an iris color classification system. The Eye Disorders Case-control Study Group. Invest. Ophthalmol. Vis. Sci. 31, 1592-1598.

Seftor, R.E., Seftor, E.A., and Hendrix, M.J. (1999). Molecular role(s) for integrins in human melanoma invasion. Cancer Metastasis Rev. 18, 359-375.

Shekar, S.N., Duffy, D.L., Frudakis, T., Sturm, R.A., Zhao, Z.Z., Montgomery, G.W., and Martin, N.G. (2008). Linkage and association analysis of spectrophotometrically quantified hair color in Australian adolescents: the effect of OCA2 and HERC2. J. Invest. Dermatol. 128, 2807-2814.

Shen, M.H., Harper, P.S., and Upadhyaya, M. (1996). Molecular genetics of neurofibromatosis type 1 (NF1). J. Med. Genet. 33, 2-17.

Shih, I.M., Elder, D.E., Hsu, M.Y., and Herlyn, M. (1994). Regulation of Mel-CAM/MUC18 expression on melanocytes of different stages of tumor progression by normal keratinocytes. Am. J. Pathol. 145, 837-845.

Simpson, T.I., and Price, D.J. (2002). Pax6; a pleiotropic player in development. BioEssays 24, 1041-1051.

Smidt, M.P., Smits, S.M., and Burbach, J.P. (2003). Molecular mechanisms underlying midbrain dopamine neuron development and function. Eur. J. Pharmacol. 480, 75-88.

Sturm, R.A. (2009). Molecular genetics of human pigmentation diversity. Hum. Mol. Genet. 18, R9-R17.

Sturm, R.A., and Frudakis, T.N. (2004). Eye colour: portals into pigmentation genes and ancestry. Trends Genet. 20, 327332.

Sturm, R.A., Duffy, D.L., Zhao, Z.Z., Leite, F.P., Stark, M.S., Hayward, N.K., Martin, N.G., and Montgomery, G.W. (2008). A single SNP in an evolutionary conserved region within intron 86 of the HERC2 gene determines human blue-brown eye color. Am. J. Hum. Genet. 82, 424-431.

Sulem, P., Gudbjartsson, D.F., Stacey, S.N. et al. (2007). Genetic determinants of hair, eye and skin pigmentation in Europeans. Nat. Genet. 39, 1443-1452.

Sulem, P., Gudbjartsson, D.F., Stacey, S.N. et al. (2008). Two newly identified genetic determinants of pigmentation in Europeans. Nat. Genet. 40, 835-837.

Swiderski, R.E., Ross, J.L., Fingert, J.H., Clark, A.F., Alward, W.L., Stone, E.M., and Sheffield, V.C. (2000). Localization of MYOC transcripts in human eye and optic nerve by in situ hybridization. Invest. Ophthalmol. Vis. Sci. 41, 3420-3428.

Szudek, J., Birch, P., Riccardi, V.M., Evans, D.G., and Friedman, J.M. (2000). Associations of clinical features in neurofibromatosis 1 (NF1). Genet. Epidemiol. 19, 429-439.

Takamoto, T., Schwartz, B., Cantor, L.B., Hoop, J.S., and Steffens, T. (2001). Measurement of iris color using computerized image analysis. Curr. Eye Res. 22, 412-419.

Ten Berge, P.J., Danen, E.H., Van Muijen, G.N., Jager, M.J., and Ruiter, D.J. (1993). Integrin expression in uveal melanoma differs from cutaneous melanoma. Invest. Ophthalmol. Vis. Sci. 34, 3635-3640.

Terman, J.S., and Terman, M. (1999). Photopic and scotopic light detection in patients with seasonal affective disorder and control subjects. Biol. Psychiatry 46, 1642-1648. 
Terzic, J., and Saraga-Babic, M. (1999). Expression pattern of PAX3 and PAX6 genes during human embryogenesis. Int. J. Dev. Biol. 43, 501-508.

Thut, C.J., Rountree, R.B., Hwa, M., and Kingsley, D.M. (2001). A large-scale in situ screen provides molecular evidence for the induction of eye anterior segment structures by the developing lens. Dev. Biol. 231, 63-76.

Ticho, B.H., Tso, M.O., and Kishi, S. (1989). Diffuse iris nevus in oculodermal melanocytosis: a light and electron microscopic study. J. Pediatr. Ophthalmol. Strabismus 26, 244-250.

Ticho, B.H., Hilchie-Schmidt, C., Egel, R.T., Traboulsi, E.I., Howarth, R.J., and Robinson, D. (2006). Ocular findings in Gillespie-like syndrome: association with a new PAX6 mutation. Ophthalmic Genet. 27, 145-149.

Van Agtmael, T., Schlotzer-Schrehardt, U., Mckie, L., Brownstein, D.G., Lee, A.W., Cross, S.H., Sado, Y., Mullins, J.J., Poschl, E., and Jackson, I.J. (2005). Dominant mutations of Col4a1 result in basement membrane defects which lead to anterior segment dysgenesis and glomerulopathy. Hum. Mol. Genet. 14, 3161-3168.

Vannas-Sulonen, K., Vannas, A., O'donnell, J.J., Sipila, I., and Wood, I. (1983). Pathology of iridectomy specimens in gyrate atrophy of the retina and choroid. Acta Ophthalmol. (Copenh) 61, 9-19.

Vasconcellos, J.P., Melo, M.B., Schimiti, R.B., Bressanim, N.C., Costa, F.F., and Costa, V.P. (2005). A novel mutation in the GJA1 gene in a family with oculodentodigital dysplasia. Arch. Ophthalmol. 123, 1422-1426.

Vasiliou, V., and Gonzalez, F.J. (2008). Role of CYP1B1 in glaucoma. Annu. Rev. Pharmacol. Toxicol. 48, 333-358.

Vidal-Taboada, J.M., Bergonon, S., Scartezzini, P., Egeo, A., Nizetic, D., and Oliva, R. (1997). High-resolution physical map and identification of potentially regulatory sequences of the human SH3BGR located in the Down syndrome chromosomal region. Biochem. Biophys. Res. Commun. 241, 321-326.

Waardenburg, P.J. (1950). Twin research in ophthalmology. Doc. Ophthalmol. 4, 154-199.

Wakamatsu, K., Hu, D.N., Mccormick, S.A., and Ito, S. (2008). Characterization of melanin in human iridal and choroidal melanocytes from eyes with various colored irides. Pigment Cell Res. 21, 97-105.

Wallis, D., and Muenke, M. (2000). Mutations in holoprosencephaly. Hum. Mutat. 16, 99-108.

Wang, P., Liang, X., Yi, J., and Zhang, Q. (2008). Novel SOX2 mutation associated with ocular coloboma in a Chinese family. Arch. Ophthalmol. 126, 709-713.
Wentzel, P., Bergh, K., Wallin, O., Niemela, P., and Stjernschantz, J. (2003). Transcription of prostanoid receptor genes and cyclooxygenase enzyme genes in cultivated human iridial melanocytes from eyes of different colours. Pigment Cell Res. 16, 43-49.

Wielgus, A.R., and Sarna, T. (2005). Melanin in human irides of different color and age of donors. Pigment Cell Res. 18, 454464.

Wilkerson, C.L., Syed, N.A., Fisher, M.R., Robinson, N.L., Wallow, I.H., and Albert, D.M. (1996). Melanocytes and iris color. Light microscopic findings. Arch. Ophthalmol. 114, 437-442.

Williamson, T.H., Garner, A., and Moore, A.T. (1991). Structure of Lisch nodules in neurofibromatosis type 1. Ophthalmic. Paediatr. Genet. 12, 11-17.

Wirbelauer, C., Karandish, A., Haberle, H., and Pham, D.T. (2005). Noncontact goniometry with optical coherence tomography. Arch. Ophthalmol. 123, 179-185.

Wistow, G., Berstein, S.L., Ray, S., Wyatt, M.K., Behal, A., Touchman, J.W., Bouffard, G., Smith, D., and Peterson, K. (2002). Expressed sequence tag analysis of adult human iris for the NEIBank Project: steroid-response factors and similarities with retinal pigment epithelium. Mol. Vis. 8, 185-195.

Wright, S. (1918). Color inheritance in mammals. J. Hered. 9, 227240.

Xu, P.X., Woo, I., Her, H., Beier, D.R., and Maas, R.L. (1997). Mouse Eya homologues of the Drosophila eyes absent gene require Pax6 for expression in lens and nasal placode. Development 124, 219-231.

Zaki, P.A., Collinson, J.M., Toraiwa, J., Simpson, T.I., Price, D.J., and Quinn, J.C. (2006). Penetrance of eye defects in mice heterozygous for mutation of $\mathrm{Gli} 3$ is enhanced by heterozygous mutation of Pax6. BMC Dev. Biol. 6, 46.

Zarbalis, K., Siegenthaler, J.A., Choe, Y., May, S.R., Peterson, A.S., and Pleasure, S.J. (2007). Cortical dysplasia and skull defects in mice with a Foxc1 allele reveal the role of meningeal differentiation in regulating cortical development. Proc. Natl. Acad. Sci. USA 104, 14002-14007.

Zhang, P., and Watanabe, K. (2007). Preliminary study on eye colour in Japanese macaques (Macaca fuscata) in their natural habitat. Primates 48, 122-129.

Zhu, G., Evans, D.M., Duffy, D.L. et al. (2004). A genome scan for eye colour in 502 twin familes: most variation is due to a QTL on chromosome 15q. Twin Res. 7, 197-210. 